\title{
Bio-weathering of granites from Eastern Dharwar Craton (India): a tango of bacterial metabolism and mineral chemistry
}

\author{
Arpitha Chikkanna $\cdot$ Devanita Ghosh $(\mathbb{D} \cdot$ K. Sajeev
}

Received: 1 September 2020/Accepted: 6 April 2021/Published online: 18 April 2021

(C) The Author(s), under exclusive licence to Springer Nature Switzerland AG 2021

\begin{abstract}
The bio-weathering process contributes majorly in the physical shaping of earth's surface. The weathering of mineral is coupled to the formation of new minerals and release of bio-available nutrients for flora as well as microbial communities. Granites from the Eastern Dharwar Craton (EDC) India are felsic plutonic igneous rock composed of nutritive minerals. The major elemental composition of granite is such that, it forms an ancient ecological niche for diverse microbial communities. Interdisciplinary approaches were taken to construct a more comprehensive understanding of potential functional attributes of Actinobacteria in bio-weathering of granite. This work includes molecular characterization of the isolated
\end{abstract}

Responsible Editor: Edith Bai.

Supplementary Information The online version contains supplementary material available at https://doi.org/10.1007/ s10533-021-00791-x.

A. Chikkanna · D. Ghosh $(\bowtie)$

Laboratory of Biogeochem-Mystery, Centre for Earth

Sciences, Indian Institute of Science, Bangalore 560012,

India

e-mail: devanita@iisc.ac.in

\section{A. Chikkanna}

Murdoch University, 90 South Street,

Perth CampusMurdoch, WA 6150, Australia

K. Sajeev

Centre for Earth Sciences, Indian Institute of Science,

Bangalore 560012, India strains, detecting their granite bioweathering potentials through leaching experiments where Nocardioides showed highest mineral leaching indices with iron $(\mathrm{Fe})$ being the most leached element ( 6372 ppm). Scanning electron microscopic imaging indicated biofilm formation and Actinobacterial hyphae colonization. Petrographic, XRD and FTIR based study shows formation of secondary minerals (kaolinite, vermiculite and smectite). To further establish the hypothesis of soil formation and nutrition transport, long-term (360 days) microcosm was developed. Deterioration and grain size alternations with increase in clay based minerals (kaolinite, vermiculite) and total protein content was observed. A bioinformatics based functional biodiversity approach in link to global bio-weathering of rocks by the genus Actinobacteria was adopted to understand their distribution patterns and contribution to alterations of rock minerals. 


\section{Graphic abstract}

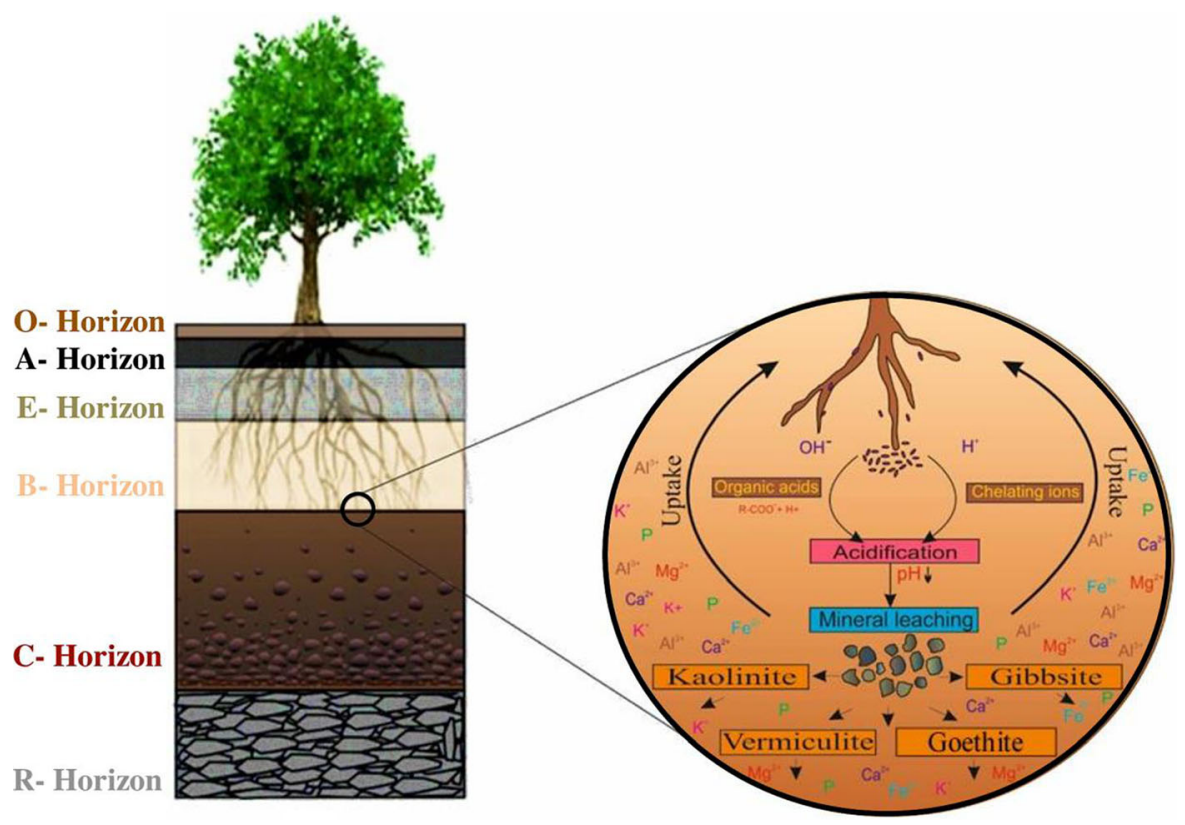

Keywords Bio-weathering - Actinobacteria . Feldspar · Plagioclase · Biotite · Biogeography

\section{Introduction}

Mineral and rock weathering are the most significant biogeochemical phenomenon occurring at the interface between the earth's endogenic and exogenic cycles. This process is an integral part of formation of soil and sediments and plays a key role in the maintenance of soil development and fertility; along with the regulation of atmospheric constitution and global climate (Uroz et al. 2009; Chikkanna and Ghosh 2018). In addition, weathering directly affects humans by exerting an impact on water quality and durability of buildings and monuments (Mailloux et al. 2009; Brewer and Fierer 2018; Chikkanna and Ghosh 2018). Transformation of bedrock through abiotic and biotic weathering processes are necessary for metabolic availability of nutrients in the earth's critical zone (Jin et al. 2010; Akob and Kusel 2011). These processes lead to mobilization of both essential elements such as $\mathrm{K}, \mathrm{Na}, \mathrm{P}, \mathrm{Ca}, \mathrm{Mg}, \mathrm{Mn}, \mathrm{Fe}, \mathrm{Cu}, \mathrm{Zn}$ and pernicious elements such as $\mathrm{Al}$ into the terrestrial ecosystem and surface and subsurface water systems
(Gadd 2010). Moreover, in nutrient deprived environments, endolithic microbes weathering rocks, play significant role in providing nutrients to the entire food chain including primary producers (Calvaruso et al. 2006; Uroz et al. 2009). Notably, in temperate forest ecosystems which develop on acidic soils, the ectomycorrhizal fungi which lives in symbiotic association with trees, exert selective pressure on soil bacterial communities (mycorrhizosphere) which enhance primary rock weathering process through production of organic acid molecules (Van Breemen et al. 2000; Uroz et al. 2009).

Recent studies report that rock colonizing microorganisms accelerate biochemical disruption and fractionation of rock minerals through physical (hyphal growth; Fig. Graphical abstract) and chemical processes (release of organic acids and chelating ions; Alekseeva et al. 2009; Abdulla et al. 2008; Brewer and Fierer 2018). However, the mechanism and rate of microbial weathering is inconsistent and dependent on certain characteristics of the rock exterior (Mapelli et al. 2012). Actinobacteria are ancient group of bacteria with inimitable ability to tolerate desiccation and to adapt and colonize in extreme environments (Ventura et al. 2007; Battistuzzi and Hedges 2009; Abdulla 2009). Their ability to decompose complex materials have contributed to the biogeochemical 
cycling of both essential nutrients and minerals over ancient years and thus, they might be the first bacterial phyla to have invaded the land masses (Battistuzzi et al. 2004; Kavil et al. 2020; Ghosh et al. 2021).

Granites are abundant igneous rocks found in EDC of peninsular India, which date back to Archaean era of 3.5-2.5 Ga (Manikyamba and Kerrich 2011). Since EDC has acted as a nutrient reservoir for large Biosphere reserves and coffee plantations of southern India, where the endolithic microbes can be the key players in sedimentation processes (Baskaran et al. 2012; Horath and Bachofen 2009). To our knowledge, this is the first study describing the active bioweathering of granite from EDC. The symbiotic involvement of biology and geology to understand the relationship of microbial communities in the formation of geological framework is very rare. In this report study of bio-weathering of granites from Bangalore which lies within the EDC belt, sets the stage, to understand the impact of granite minerals in nurturing the vegetation of EDC belt. The objectives of this study are to: (1) Study the role of indigenous micro-endoliths in bio-weathering of EDC-granites, (2) Understand the role of short and long term bioleaching processes in mobilizing minor and major nutrients, and their contribution to the biogeochemical fluxes in the ecosystem. (3) Develop a comparative biogeographical model for Actinobacterial weathering of rocks.

\section{Materials and methods}

Study area and sampling procedure

The EDC in the southern India contains abundant granite plutons with late Archaean evidence for biological weathering. The sampling site Bangalore District, Karnataka, India (N $13^{\circ} 01^{\prime} 16.15^{\prime \prime}$, E $77^{\circ}$ $\left.34^{\prime} 13.91^{\prime \prime}\right)$ is located at the centre of the southern Indian peninsula (Fig. 1), $934 \mathrm{~m}$ above sea level, only $\sim 300 \mathrm{~km}$ away from Arabian sea, with a tropical climate. The average annual rainfall is $960 \mathrm{~mm}$ from the moisture produced in the two adjoining seas, Bay of Bengal and the Arabian Sea. It receives rainfall from both the SW and NE monsoons and the summers are more wetter than the winters (Rahul et al. 2016). According to the Köppen-Geiger climate classification, the climate in this region was considered to be Aw. The average annual temperature is $\sim 22.9^{\circ} \mathrm{C}$ or $73.1{ }^{\circ} \mathrm{F}$ and the average annual rainfall is $960 \mathrm{~mm}$, with an average annual humidity of $65.16 \%$. This site mainly forms a part of EDC which is a natural cross section of late Archaean continental nuclei. The granite samples present in various weathered conditions were identified and collected from the monoliths. The weathered samples were obtained from the surface (Fig. 1a) and non-weathered samples from 1 to $2 \mathrm{~m}$ depth from a large monolith (Fig. 1b) using sterile hammer and chisel blade, collected in separate sterile polythene bags and stored at $4{ }^{\circ} \mathrm{C}$, prior to processing.

Petrographical and mineralogical studies

Petrographic study of the samples was carried out in polished thin sections under a Petrological Microscope-Olympus BX51 to understand the mineral assemblages. The mineral composition of respective minerals was obtained by using JEOL JXA-8230 Electron Probe Micro Analyser (EPMA) housed at Advanced Facility for Microscopy and Microanalysis (AFMM), IISc, Bangalore. The probe (beam) current during analysis was $12 \mathrm{nA}$ and acceleration voltage $15 \mathrm{kV}$. Natural and synthetic silicates and oxides were used for calibration. Standard ZAF correction procedure was used for data reduction. The rock thin sections were carbon coated prior to analysis.

Genotypic and phenotypic characterization

\section{Enrichment of actinobacterial strains}

The collected rock samples were aseptically cut into small chips and crushed into fine powder using sterile mortar and pestle. The Actinobacteria isolation was carried out as previously described (Abdulla et al. 2008), using Starch Casein Agar (composition: Soluble starch $10 \mathrm{~g} / \mathrm{l} ;$ Casein $0.30 \mathrm{~g} / \mathrm{l} ; \mathrm{KNO}_{3} 2 \mathrm{~g} / \mathrm{l}$; $\mathrm{MgSO}_{4} \cdot 7 \mathrm{H}_{2} \mathrm{O} 0.05 \mathrm{~g} / \mathrm{l} ; \mathrm{K}_{2} \mathrm{HPO}_{4} 2 \mathrm{~g} / \mathrm{l} ; \mathrm{NaCl}_{2}$ and $\mathrm{CaCO}_{3} 0.02 \mathrm{~g} / \mathrm{l} ; \mathrm{FeSO}_{4} \cdot 7 \mathrm{H}_{2} \mathrm{O} 0.01 \mathrm{~g} / \mathrm{l}$; Agar $\left.18 \mathrm{~g} / \mathrm{l}\right)$ and Actinobacteria Isolation Agar (Sigma-Aldrich/HiMedia). The plates were prepared in triplicates for each sample and were incubated in inverted condition at $30{ }^{\circ} \mathrm{C}$ for $3-5$ days. 


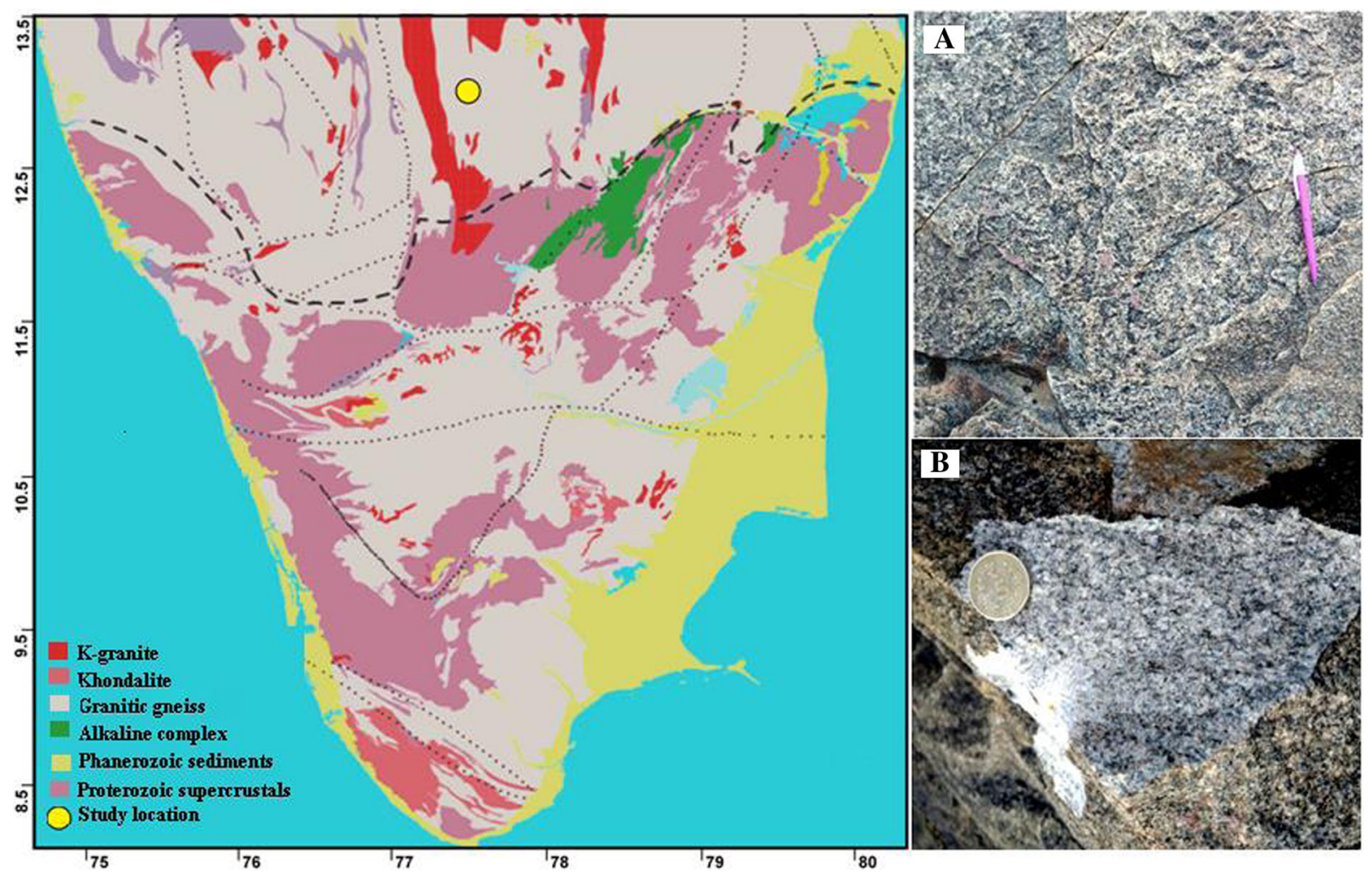

Fig. 1 a Geological study map of peninsular of India (Left). Field photographs of granite sample (Right) b Highly weathered granite surface, $\mathbf{c}$ Non-weathered granite surface

\section{Biochemical characterization}

The biochemical characterization of the isolates was detected by oxidation of $1 \% \mathrm{p}$-amino dimethylaniline oxalate and catalase activity using $3 \%(\mathrm{v} / \mathrm{v}) \mathrm{H}_{2} \mathrm{O}_{2}$ solution. The carbon substrate utilization pattern of the isolates was performed with Carb Kit (HiMedia) following the manufacturer's instructions (Table 1).

\section{Taxonomic characterization}

Taxonomic characterization of the isolated strains were done using single bacterial colony by colonypolymerase chain reaction (PCR) based amplification of 16S rRNA gene using eubacterial primer Fc27 (5'AGAGTTTGATCCTGGCTCAG-3') and Rc1492 (5'TACGGCTACCTTGTTACGACTT-3'; Lane 1991). The PCR reaction mixtures and amplification conditions were carried out as previously described (Chikkanna et al. 2018). The PCR reactions (Veriti, $\mathrm{AB})$ were performed in triplicates pooled down and purified using Gel Purification Kit (Qiagen, Hilden,
Germany) as per manufacturer's instructions. The purified product was then sequenced in both directions using same primers in an ABI Prism 3730 Genetic Analyzer based on Big Dye Terminator chemistry (Applied Biosystems, California, United States). Sequences were checked in Bellerophon (Huber et al. 2004) for chimera and had been submitted to GenBank database. The accession numbers are MH726216 for 16S rRNA gene sequence of Nocardioides salarius strain BLR1 and MH726217 for Nocardioides bigeumensis strain BLR2.

Nucleotide sequence accession number

The GenBank/EMBL/DDBJ accession number for the 16S rRNA gene of Nocardioides salarius strain BLR1 is MH726216 and for Nocardioides bigeumensis strain BLR2 is MH726217. 
Table 1 Biochemical characterization of Nocardioides salarius strain BLR1and for Nocardioides bigeumensis strain BLR2

\begin{tabular}{|c|c|c|}
\hline \multirow[t]{2}{*}{ Phenotypic profiles } & \multicolumn{2}{|c|}{ Nocardioides salarius strain } \\
\hline & BLR-1 & BLR-2 \\
\hline Gram character & + & + \\
\hline Catalase activity & + & + \\
\hline Oxidase activity & + & + \\
\hline Starch hydrolysis activity & + & + \\
\hline Esculin activity & + & + \\
\hline Nitrate reductase activity & - & - \\
\hline \multicolumn{3}{|l|}{ Carbohydrate utilization } \\
\hline Lactose & - & - \\
\hline Xylose & + & + \\
\hline Maltose & + & + \\
\hline Fructose & + & + \\
\hline Dextrose & + & + \\
\hline Galactose & + & + \\
\hline Raffinose & - & - \\
\hline Trehalose & - & - \\
\hline Melibiose & - & - \\
\hline Sucrose & + & + \\
\hline L-Arabinose & + & + \\
\hline Innulin & + & + \\
\hline Sodium Gluconate & - & - \\
\hline Glycerol & + & + \\
\hline Salicin & - & - \\
\hline Dulcitol & + & + \\
\hline Inositol & + & + \\
\hline Sorbitol & + & + \\
\hline Mannitol & - & - \\
\hline Adonitol & - & - \\
\hline Arabitol & + & + \\
\hline Erythritol & + & + \\
\hline$\alpha$-methyl D manoside & - & - \\
\hline Xylitol & + & + \\
\hline ONPG & + & + \\
\hline D-Arabinose & - & - \\
\hline Citrate utilization & + & + \\
\hline Malonate utilization & - & - \\
\hline Sorbose & - & - \\
\hline
\end{tabular}

+ indicates positive result/isolate is able to utilize the $\mathrm{C}$ source - indicates negative result/ isolate is unable to utilize the $\mathrm{C}$ source ONPG is ortho-nitrile $\beta$ D-galactopyranoside
Phylogenetic analysis

The sequences were then compared with the nucleotide databases (GenBank/EMBL/DDBJ) using NCBI BLAST program (Camacho et al. 2009). The top ten similar 16S rRNA gene sequences in the match results were selected for each isolate and used for phylogenetic representation. The sequences were aligned using Clustal Omega tool (Sievers et al. 2011). The software MEGA (Version 5.0) was used for phylogenetic analysis (Tamura et al. 2007). The phylogenetic representation for the sequences was carried out using Neighbour-joining (NJ) method (Saitou and Nei 1987) based on Kimura 2 parameter model (Kimura 1980) for constructing the tree. Bootstrap test of 1000 replicates was conducted to get best topology (Felsenstein 1985). To root the phylogenetic tree, the $16 \mathrm{~S}$ rRNA gene sequence of Methanobrevibacter smithii strain B181 (Acc. No. U55235) was used as an outgroup.

DNA G + C content

To estimate the $\mathrm{G}+\mathrm{C}$ content, DNA was degraded into nucleosides, enzymatically (Mesbah et al. 1989). The degraded product was then separated in HPLC (Shimadzu) using an analytical column (Vydac 201 SP54, C18, $5 \mathrm{~mm} ; 250 \times 4.6 \mathrm{~mm}$ ) equipped with a guard column (201 GD54H; Vydac; Tomaoka and Komagata 1984) and the non-methylated lambda phage DNA (Sigma) was used as reference.

\section{Phospholipo fatty acid (PLFA) characterization}

Approximately $50 \mathrm{mg}$ of the freeze-dried cell pellet of the strain BLR-1 in log-phase was used to extract membrane fatty acids and fractionate them using short phase extraction column as described earlier by Ghosh et al. (2018). The methylated PLFAs were identified and quantified by gas chromatography-mass spectrometry (GC-MS; Ghosh et al. 2018). Deuterated eicosanoic acid methyl ester (d-EAME) was used as an internal standard to a spike of $10 \mathrm{mg} / \mathrm{l}$.

Granite bio-weathering experiments

Granite weathering experiments for three different analyses were carried out using modified starch casein broth in triplicates for the measurements of leached 
out elemental concentrations and Scanning Electron Microscopy (SEM) analysis. The experiments were carried out in $500 \mathrm{ml}$ Erlenmeyer culture flasks each containing $250 \mathrm{ml}$ of the modified media with $10 \mathrm{~g}$ of granite rock powder and $\mathrm{pH}$ was adjusted to 7 with $10 \mathrm{mM} \mathrm{NaOH}$. The media used for SEM analysis contained $1 \mathrm{~cm}$ rock chip (Pre-weighed) instead of rock powder. Those were then inoculated with previously isolated Actinobacterial strain cultures and incubated at $30{ }^{\circ} \mathrm{C}$ in a rotary shaker at $150 \mathrm{rpm}$ for 40 days. The $\mathrm{pH}$ was monitored every 5 th day using pH 213 Microprocessor (Hanna). The cells were stained with crystal violet and observed using biological microscope for mycelia growth.

\section{Microcosm setup}

Two sacrificial microcosms were set up as Set A: by mixing $5 \mathrm{~kg}$ sterilized and dried block of granite rock with $50 \mathrm{ml}$ actively growing (Optical density 1; in Actinobacteria media mentioned above), mixed culture of the isolated Actinobacterial strains, and Set B (control set): mixing $5 \mathrm{~kg}$ sterilized dry block of granite rock with $50 \mathrm{ml}$ sterile Actinobacteria media). Both the sets were sealed and incubated for 360 days in aphotic condition at $10{ }^{\circ} \mathrm{C}$ (to mimic soil zone B; Graphical abstract) and $90 \%$ relative humidity. The rock in set A became brittle, whereas the rock in set $\mathrm{B}$ remain unaltered is powdered for further analysis. After the incubation period, the texture (grain size), mineral composition and leached elements were measure as described above. The total protein content was measured using Bradford's assay (Bradford 1976; Halvorson and Gonzalez 2006), which can be also interpreted as Bradford reactive soil protein (BRSP), however, the source of the protein is only the microbial hypae.

Chemical analyses of the rock samples

(i) X-Ray Diffraction (XRD) based mineralogical analyses The mineral composition of a) initial weathered section of the granite sample from bio-weathering experiment (40 days incubation) and the post microcosm incubation (360 days incubation) were determined by using XRD based irradiation of samples (Rigaku, Smart lab powder X-Ray
Diffractometer). The source used during analysis was $\mathrm{CuK} \alpha$ radiation, acceleration voltage of $40 \mathrm{kV} / 30 \mathrm{~mA}$ with D/Tex Ultra detector. The samples were finely powdered, centrifuged and $<2 \mu$ particles were used to prepare the oriented slides in three sets: air dried (air-dried oriented aggregates (AO), solvated with ethylene glycol at $60{ }^{\circ} \mathrm{C}$ for $16 \mathrm{~h}(\mathrm{AO}+\mathrm{EG})$, and heated at $500{ }^{\circ} \mathrm{C}$ for $2 \mathrm{~h}(\mathrm{AO}+\mathrm{T})$ (Moore and Reynolds 1989).

(ii) Fourier Transformation Infrared Spectroscopy based mineralogical analysis For a comparative analysis of the mineral characteristics due to long term microcosm based bio-weathering, the powdered particles were also characterized using a PerkinElmer Spectrum Two FT-IR Spectrometer.

(iii) Inductively Coupled Plasma Mass Spectrometry (ICP-MS) based leaching quantifications The leached-out elements were quantified using ICP-MS (Thermo Scientific X-Series II equipped with Quadrupole mass analyser and Nickel sample and skimmer cones). For this, $1 \mathrm{~g}$ of each sample from bio-weathering experiment was crushed using sterile agate mortar and pestle. The sample dissolution using acids was carried out as previously described (Banerjee et al. 2016). For elemental concentration determination, $\sim 25 \mathrm{mg}$ of each sample was dissolved using a mixture of $1 \mathrm{ml}$ of $1 \mathrm{~N} \mathrm{HF}$ and $1 \mathrm{ml}$ of $1 \mathrm{~N} \mathrm{HNO}_{3}$ at $120{ }^{\circ} \mathrm{C}$. The acid mixture was evaporated after $24 \mathrm{~h}$ of reaction and a mixture of $1 \mathrm{ml}$ of $1 \mathrm{~N} \mathrm{HNO}_{3}$ and $1 \mathrm{ml}$ of $1 \mathrm{~N} \mathrm{HCl}$ was added to the samples. After another $24 \mathrm{~h}$ of incubation at $120^{\circ} \mathrm{C}$, the acids were evaporated, and the residue was dissolved in $2 \mathrm{ml}$ of $1 \mathrm{~N} \mathrm{HNO}_{3}$ and transferred to $125 \mathrm{ml}$ pre-cleaned HDPE bottles. The internal standards were used as previously described (Banerjee et al. 2016).

To determine the concentration of the dissolved major and minor elements, highly sensitive method of ICP-MS with No-CCT mode was used. USGS rock standards BHVO-2 (Hawaiian basalt) and BCR-2 (Columbia River basalt) were used as calibration standards. The USGS rock standard AGV-2 (Andesite) was analysed to test the accuracy of the data. All the USGS standards were processed the same way as 
the rock samples. The detection limits for all elements of the ICP-MS were within $0.1 \mathrm{mg} / \mathrm{l}$.

Bio-weathering evidences from Scanning Electron Microscopy (SEM)

The weathered rock material was examined by SEM for the presence of Actinobacterial hyphae colonization. The chips were removed from the flasks using sterile forceps, air dried and coated with gold. They were examined using SEM JSM IT-300 instrument with accelerating voltage of $15 \mathrm{kV}$ and $7-11 \mathrm{~mm}$ working distance. The weathered fragments were also examined using ESEM.

Biogeographic diversity of weathering

Actinobacteria involved in weathering

The diversity studies were carried out by targeting previously studied Actinobacterial strains involved in environmental bio-weathering process (Supplementary Table 1). The 16S rRNA gene sequences were retrieved from the nucleotide databases (GenBank/ EMBL/DDBJ). Clustal Omega tool was used to align the sequences (Sievers et al. 2011). Phylogenetic tree was constructed using similar parameters described in the above Section 2.6. The diversity parameters were calculated using DOTUR Program.

Statistical analysis of biogeography metadata

To understand the bacterial diversity and for taxonomical analysis, the generated sequences were grouped into Operational Taxonomic Units (OTU) based on $3 \%$ cut-off at nucleotide level for $16 \mathrm{~S}$ rRNA gene sequences using DOTUR (Schloss and Handelsman 2005). The Shannon-Wiener $\left(\mathrm{H}^{\prime}\right)$ and Simpson indices were calculated for measurement of biodiversity of the Actinobacterial genera in environmental bio-weathering process. Phylotype frequency curves were prepared to determine the frequency of OTUs across the Actinobacterial genera. Rarefaction analysis was undertaken in DOTUR to understand the sampling biasness.

\section{Results}

Petrology and mineral chemistry studies

The coarse-grained interlocking plagioclase-K-feldspar-quartz-biotite (Pl-Kfs-Qtz-Bt) assemblage is typical of granitic rocks (Fig. 2a). Textural alterations with Actinobacterial intergrowth within plagioclase grain indicate weathering initiation (Fig. 2b). The representative microprobe point (WDS) analyses of minerals are listed in Table 2. Plagioclase contains $\mathrm{Na}_{2} \mathrm{O}$ which is $12.87 \mathrm{wt} \%$ indicating plagioclase feldspar is albitic rich. In case of $\mathrm{K}$-feldspar, $\mathrm{K}_{2} \mathrm{O}$ is $13.33 \mathrm{wt} \%$. There are other K-bearing minerals like $\mathrm{Bt}$ $\left(\mathrm{K}_{2} \mathrm{O}-10.89 \mathrm{wt} \%\right.$ and $\left.\mathrm{FeO}-26.85 \mathrm{wt} \%\right)$ present in the sample. The mineral chemistry of biotite suggests that it is Fe rich annite.

Other analytical studies

The biochemical alterations of granite were detected from the mineralogical compositions. Along with the primary minerals of granite (Fig. 3), determined by XRD analysis which includes quartz $(3.33 \AA)$, plagioclase $(3.1 \AA)$, K-feldspar $(3.7 \AA)$ and biotite $(10.1 \AA)$, secondary clay minerals like kaolinite (7.1 ̊), illite $(9.9 \AA)$, chlorite $(14.1 \AA)$, vermiculite (4.77 $\AA$ ) and smectite $(17 \AA)$ were also detected (Fig. 4). The characteristics of these minerals were further explained using FTIR analysis (Fig. 5; Supplementary Table 1).

Bio-weathering and $\mathrm{pH}$ changes

In the bio-weathering of granite by Actinobacterial isolates, the modified starch casein broth was used to understand the change in $\mathrm{pH}$ over the incubation period, in the growth media. The $\mathrm{pH}$ of the inoculated media decreased during the initial lag phase from 7.0 to between 5.5 and 6.0. A gradual increase in $\mathrm{pH}$ from 6.0 to 7.5 was observed during exponential growth phase. During the stationary phase and death phase, the $\mathrm{pH}$ value increased between 7.5 to 8.5 and remained there (Fig. 6b).

Quantitative analyses of leaching

Dissolution experiment was carried out to better understand the mechanisms of granite dissolution by 
A

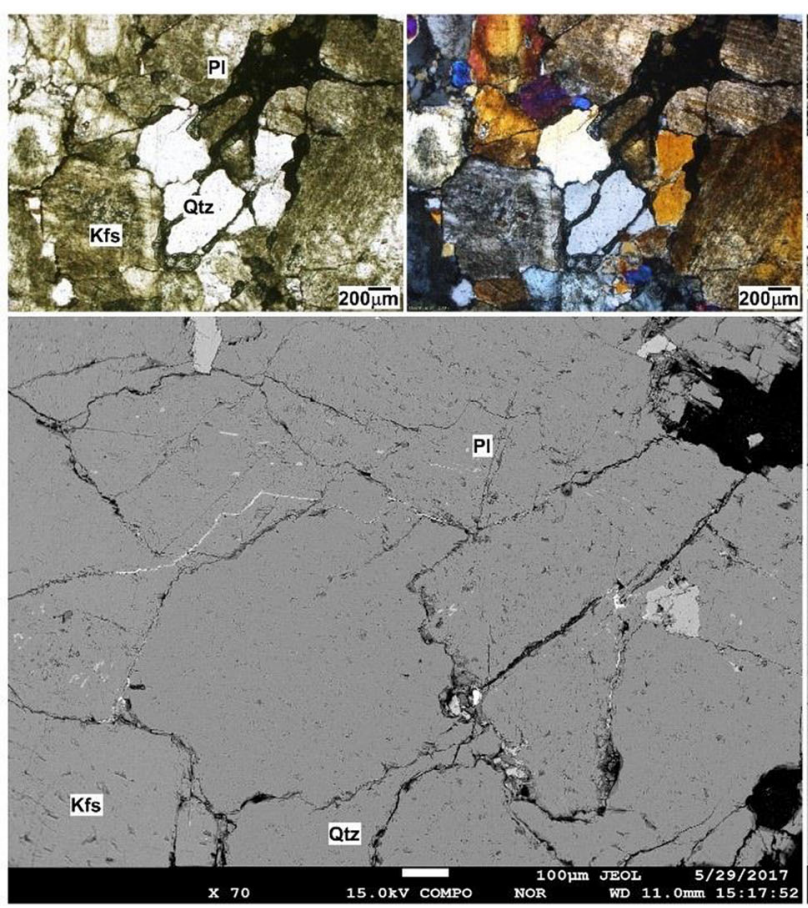

Fig. 2 a (Top) XPL (Cross-Polarized Light) image of nonweathered granite $(2 \times)$. (Bottom) BSE image of non-weathered granite illustrating quartz, K-feldspar and plagioclase mineral assemblage $(70 \times)$. b (Top) XPL (Cross-Polarized Light) image

Actinobacterial isolates and to measure the concentrations of leached-out elements. The concentrations (ppm) of elements such as $\mathrm{Na}, \mathrm{Mg}, \mathrm{Al}, \mathrm{P}, \mathrm{K}, \mathrm{Ca}, \mathrm{Fe}$ and $\mathrm{Mn}$ were measured using ICP-MS. The maximum leached out concentrations of elements was observed in cultures of isolate BLR1 and BLR2. No leaching was observed in cultures of isolate BLR3, BLR4, BLR5 and BLR6. Iron (Fe) was the most leached element with average concentration of $6372 \mathrm{ppm}$ in the culture set in comparison to $7622 \mathrm{ppm}$ in granite bearing control sets. In contrast, $\mathrm{Al}$ and $\mathrm{K}$ were the least precipitated elements (Table 3; Fig. 6a). The elemental concentrations in the extracts for the USGS standard AGV-2 (Andesite) were compared to the 95\% confidence interval (Raczek et al. 2007), and were within the confidence limit. The biochemical and carbon substrate assimilation test of the isolates is detailed in Table 1.
B

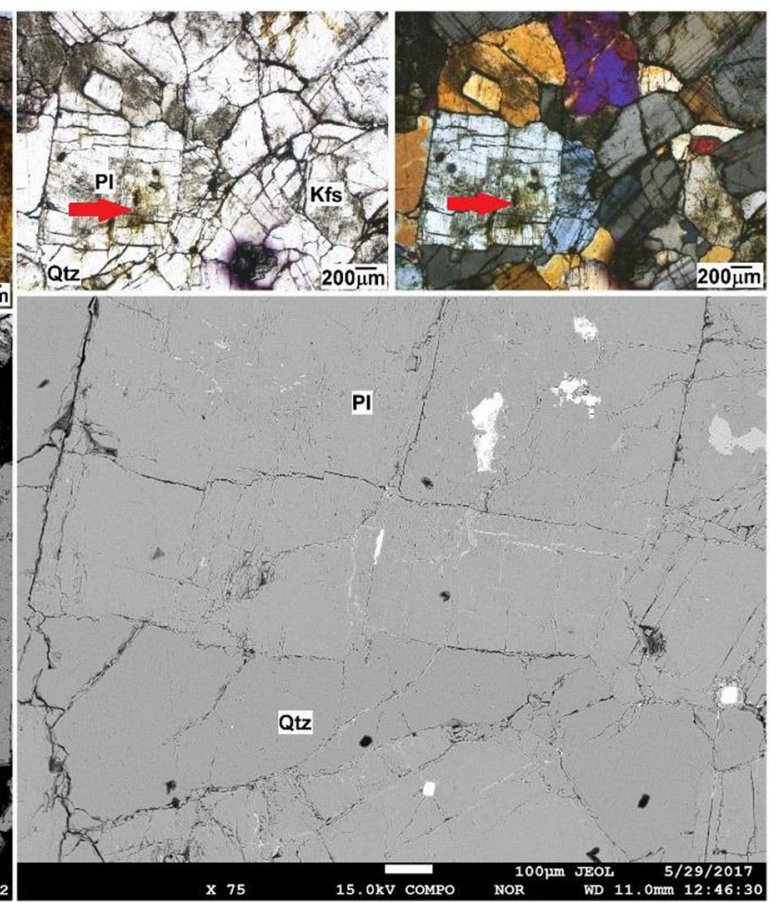

of weathered granite $(2 \times)$ showing mineral alteration and Actinobacterial intergrowth within plagioclase grain (arrow). (Bottom) BSE image of weathered granite illustrating quartz and plagioclase mineral assemblage $(75 \times)$

Microbial alteration of granite surface

The morphology of Actinobacterial hyphae growing on the granite surface were examined by light microscopy (Fig. 6d). The surface alterations and microbial growth were observed through SEM and ESEM. The SEM images (Fig. 6a) of experimental granite sample section, displays altered mineral grains with rough surface; Fig. $6 \mathrm{~b}$ is showing cells forming a biofilm on weathered granite sample surface. The weathered mineral fragment with mycelia growth displayed through ESEM microphotograph (Fig. 6c).

After a 360 days incubation, the microcosm experiment and control setups were compared to understand the physical, chemical and biological alterations, to understand the bio-weathering aspects clearly. The experimental setup mostly disintegrated into fine clay $(<0.002 \mathrm{~mm} ; 0.16 \% \mathrm{w} / \mathrm{v})$, silt $(0.002$ to $0.05 \mathrm{~mm}$; $0.69 \% \mathrm{w} / \mathrm{v})$, sand $(0.05$ to $2 \mathrm{~mm} ; 7.23 \% \mathrm{w} / \mathrm{v})$, gravels $(2-75 \mathrm{~mm} ; 26.31 \% \mathrm{w} / \mathrm{v})$ and small porous rocks (7.5-10 cm; 63.2\%), whereas no change was observed in the experimental setup (Supplementary Fig. 1). The 
Table 2 Representative mineral chemistry of granite sample

\begin{tabular}{|c|c|c|c|}
\hline $\mathrm{Wt} \%)$ & K-Feldspar & Plagioclase & Biotite \\
\hline \multicolumn{4}{|l|}{ Oxides } \\
\hline $\mathrm{SiO}_{2}$ & 64.24 & 65.60 & 34.72 \\
\hline $\mathrm{TiO}_{2}$ & 0.00 & 0.00 & 3.05 \\
\hline $\mathrm{Al}_{2} \mathrm{O}_{3}$ & 22.01 & 21.00 & 14.42 \\
\hline $\mathrm{Cr}_{2} \mathrm{O}_{3}$ & 0.00 & 0.02 & 0.01 \\
\hline $\mathrm{FeO}$ & 0.00 & 0.09 & 26.85 \\
\hline $\mathrm{MnO}$ & 0.01 & 0.00 & 0.53 \\
\hline $\mathrm{MgO}$ & 0.00 & 0.00 & 6.22 \\
\hline $\mathrm{CaO}$ & 0.00 & 2.23 & 0.00 \\
\hline $\mathrm{Na}_{2} \mathrm{O}$ & 0.52 & 12.87 & 0.03 \\
\hline $\mathrm{K}_{2} \mathrm{O}$ & 13.33 & 0.16 & 10.89 \\
\hline Total & 100.11 & 101.97 & 96.72 \\
\hline \multicolumn{4}{|l|}{ Cations } \\
\hline $\mathrm{O}$ & 8 & 8 & 22.00 \\
\hline $\mathrm{OH}$ & 0.000 & 0.000 & 4.00 \\
\hline $\mathrm{Si}$ & 2.981 & 2.862 & 5.51 \\
\hline $\mathrm{Ti}$ & 0.000 & 0.000 & 0.36 \\
\hline $\mathrm{Al}$ & 0.975 & 1.080 & 2.70 \\
\hline $\mathrm{Cr}$ & 0.000 & 0.001 & 0.00 \\
\hline $\mathrm{Fe}$ & 0.000 & 0.003 & 3.56 \\
\hline $\mathrm{Mn}$ & 0.000 & 0.000 & 0.07 \\
\hline $\mathrm{Mg}$ & 0.000 & 0.000 & 1.47 \\
\hline $\mathrm{Ca}$ & 0.000 & 0.104 & 0.00 \\
\hline $\mathrm{Na}$ & 0.047 & 1.089 & 0.01 \\
\hline $\mathrm{K}$ & 1.103 & 0.009 & 2.20 \\
\hline Total & 5.046 & 5.148 & 19.89 \\
\hline
\end{tabular}

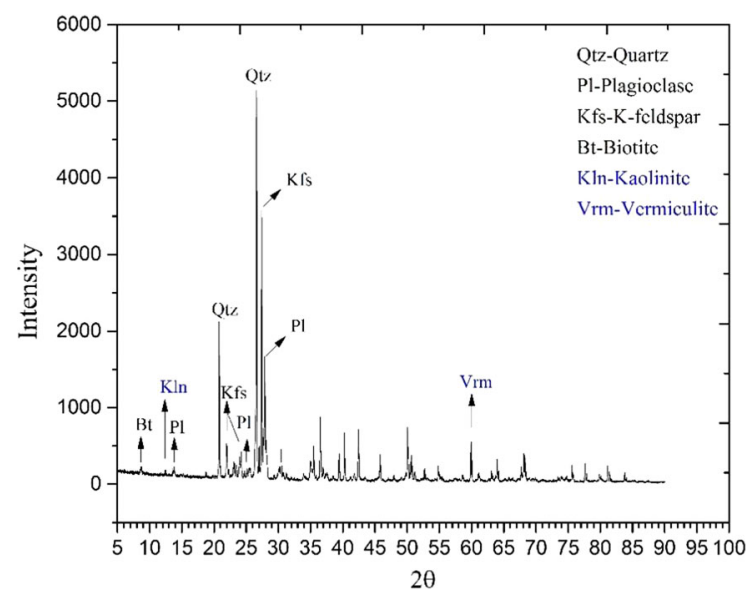

Fig. 3 X-ray diffraction of the source rock sample indicating primary minerals

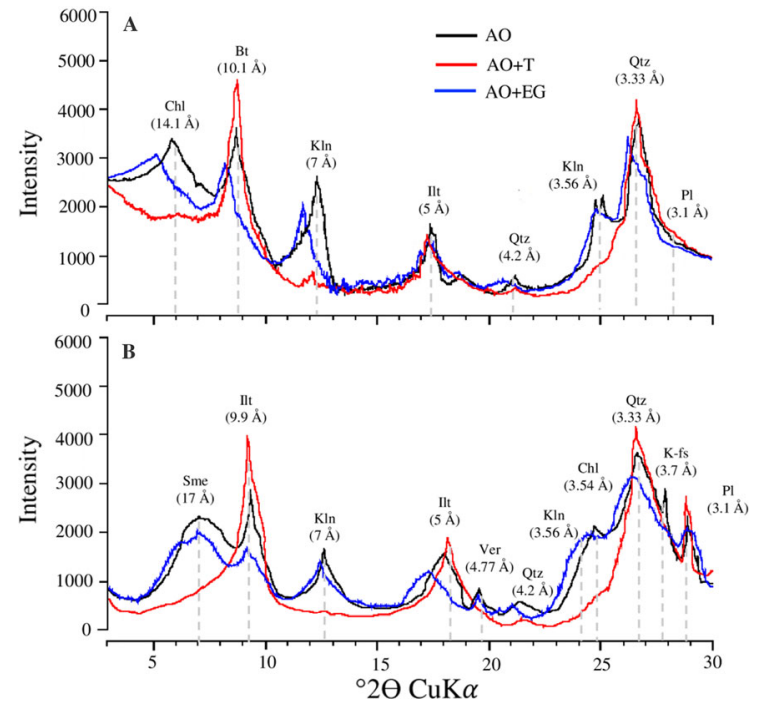

Fig. 4 X-ray diffraction of the bio-weathered samples a Short incubation - 40 days. b Long incubation- microcosm study (360 days). The samples were treated as air-dried oriented aggregates (AO), solvated with ethylene glycol at $60{ }^{\circ} \mathrm{C}$ for $16 \mathrm{~h}$ $(\mathrm{AO}+\mathrm{EG})$, and heated at $500{ }^{\circ} \mathrm{C}$ for $2 \mathrm{~h}(\mathrm{AO}+\mathrm{T})$, and analysed

XRD data of the clay fraction showed formation of secondary minerals like kaolinite and vermiculite. The average BRSP of clay fraction was $3.67 \mathrm{mg} / \mathrm{cm}^{3}$, which is similar to $10-20 \mathrm{~cm}$ deep forest soil (Halvorson and Gonzalez 2006).

Molecular identification and taxonomy

The 16S rRNA gene sequence of the isolate BLR1 and BLR2 showed 99\% identity with Nocardioides salarius strain J112 (Acc. No. NR_044419), and Nocardioides bigeumensis strain MSL-19 (Acc. No. NR_044230) respectively, at nucleotide level and inferred as Nocardioides salarius strain BLR1 and Nocardioides bigeumensis strain BLR2 (Supplementary Table 2). The phylogenetic identification of both the strains BLR1 and BLR2 indicated that they belong to the bacterial phylum Actinobacteria, under the class Actinobacteria, order Propionibacteriales, family Nocardioidaceae (Fig. 7).

GC content

The GC content of strain BLR-1 was $39.63 \%$ and strain BLR-2 was $39.21 \%$. 


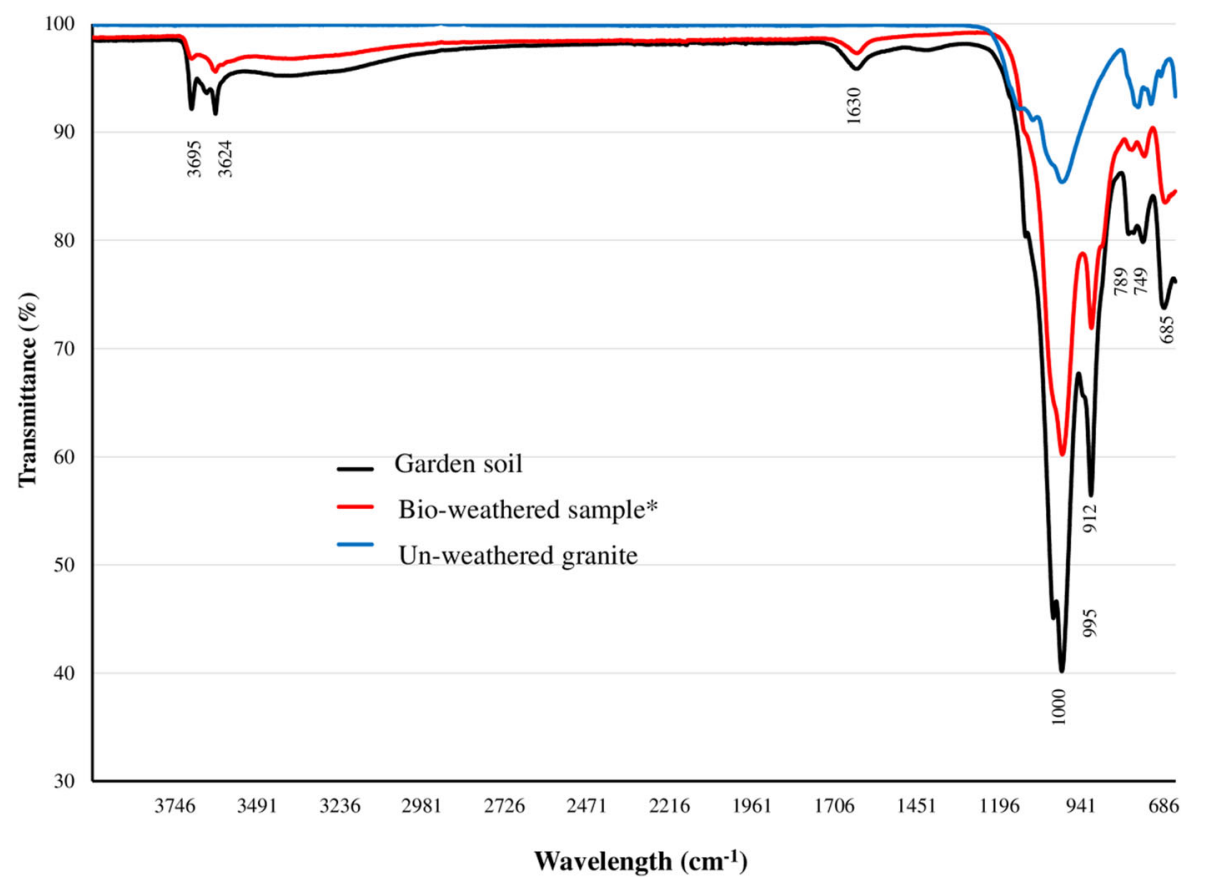

Fig. 5 The FTIR transmittance vs wavelength indicating corresponding species identification in the samples: un-weathered granite and bio-weathered granite -microcosm study

\section{PLFA analysis}

The predominant membrane PLFAs of both the strain BLR-1and BLR-2 were C14:0, C16:0, C16:1, C18:0, and $\mathrm{C} 18: 1$. The Gram positive specific fatty acids Ci15:0, Ca15:0, Ci16:0, Ci17:0 and Ca17:0 were lesser predominant and the signature PLFAs for the phylum Actinobacteria 10Me16:0, 10Me19:0 (Kroppenstedt 1985), were detected in both the strains.

\section{Actinobacterial biogeography model}

Diversity study of phylum Actinobacteria was carried out to understand their distribution patterns and involvement in bio-weathering of rock minerals (Supplementary Fig. 2). From the large metadata set our group is working on, for this study, 99 Actinobacterial $16 \mathrm{~S}$ rRNA were selected based on their mineral interaction properties. The distribution of Actinobacterial genera within their respective order is represented in Fig. 8. In the Neighbour-joining phylogenetic tree, the identified $16 \mathrm{~S}$ rRNA gene sequences could be classified into the primary orders Propionibacteriales, Micrococcales, Streptomycetales, Pseudonocardiales, Corynebacteriales,
(360 days). The garden soil sample was used as a reference to identify the secondary clay mineral species

Frankiales, Actinomycetales, Geodermatophilales and Rubrobacterales. Among them, Propionibacteriales was the most dominant order with $31 \%$ of the sequences, followed by Micrococcales (20\% of sequences) and Streptomycetales (15\% of sequences; Fig. 9a). The largest clade Propionibacteriales consisted of a sub-clade belonging to the family Nocardioidaceae which included sequences from this study (Strains BLR1 and BLR2), along with published cultured and uncultured Actinobacterial genera.

Under the order Micrococcales, four sub-clades were observed which were represented by the families Brevibacteriaceae, Intrasporangiaceae, Microbacteriaceae and Micrococcaceae; and the order Corynebacteriales consisted of two sub-clades represented by the families Nocardiaceae and Mycobacteriaceae. Whereas, the remaining clades consisted of sub-clades represented by single families as shown in (Fig. 8).

Statistical analysis of actinobacterial biogeography

Based on OTU distribution, all 99 Actinobacterial genera were grouped into 42 Operational Taxonomic 

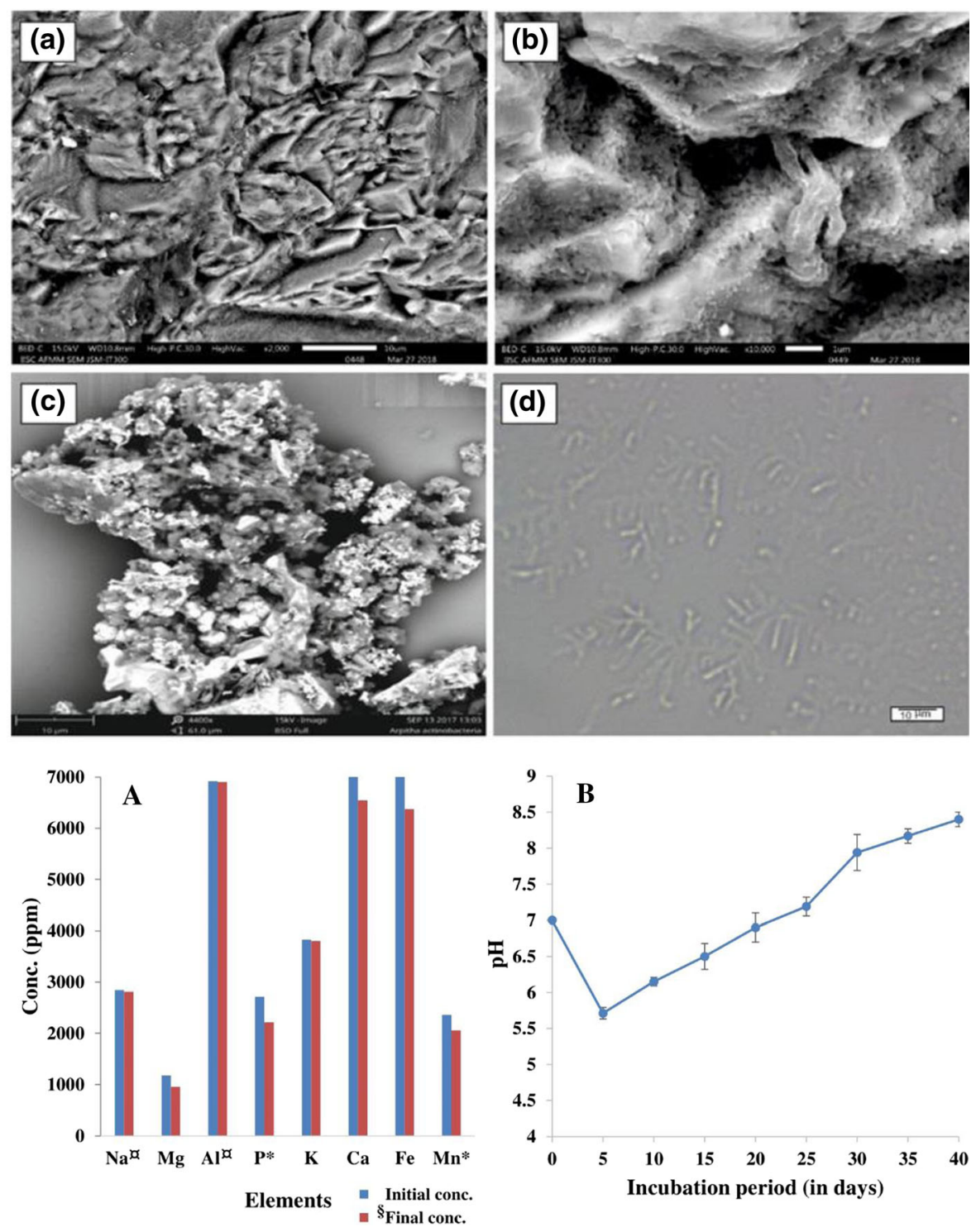

Fig. 6 A SEM and ESEM photomicrographs of the mineral surface. a Surface of mineral showing alterations $(2000 \times)$, b 242 Biofilm formation on mineral surface $(10,000 \times)$, c ESEM image of weathered fragment with mycelia growth 243 $(4400 \times)$. d Light microscopy image of Nocardioides sp.

BLR2 hyphae $(100 \times)$. B Leaching of elements indicated by the increase in final setup (post-experiment) relative to initial fluxes. C Acid dynamics during the growth phase (mean; $\mathrm{n}=3$ ) in of bio-weathering experimental setup

Table 3 Elemental concentrations of weathered granite in contrast with initial

\begin{tabular}{lllllllll}
\hline & $\begin{array}{l}\mathrm{Na} \\
\mathrm{ppm}\end{array}$ & $\begin{array}{l}\mathrm{Mg} \\
\mathrm{ppm}\end{array}$ & $\begin{array}{l}\mathrm{Al} \\
\mathrm{ppm}\end{array}$ & $\begin{array}{l}\mathrm{P} \\
\mathrm{ppm}\end{array}$ & $\begin{array}{l}\mathrm{K} \\
\mathrm{ppm}\end{array}$ & $\begin{array}{l}\mathrm{Ca} \\
\mathrm{ppm}\end{array}$ & $\begin{array}{l}\mathrm{Fe} \\
\mathrm{ppm}\end{array}$ & $\begin{array}{l}\mathrm{Mn} \\
\mathrm{ppm}\end{array}$ \\
\hline Initial concentration $^{\mathrm{a}}$ & 28,460 & 1176 & 69,210 & 271.6 & 38,290 & 7055 & 7622 & 236.2 \\
Average of triplicates $^{2}$ & 28,110 & 954.7 & 69,020 & 221.6 & 38,030 & 6547.5 & 6372 & 205.65 \\
\hline
\end{tabular}

${ }^{\mathrm{a}}$ Concentrations prior to weathering 


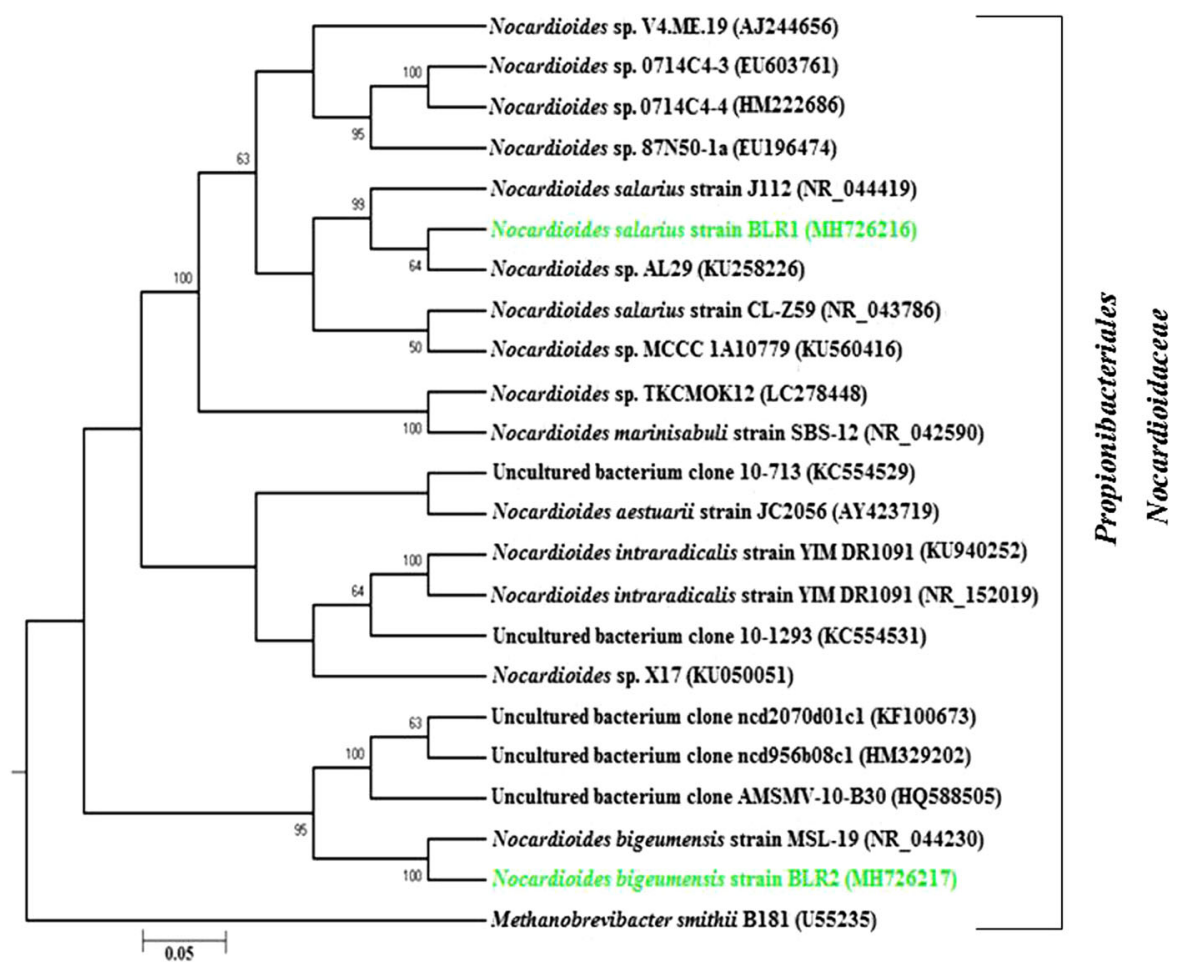

Fig. 7 Neighbour joining phylogenetic tree of 16S rRNA gene sequences of the studied Nocardioides isolates (strain BLR1 and strain BLR2 in green) and their closest cultured and uncultured

Units (OTUs), with a cut-off of 3\% at nucleotide level (Fig. 9b). The diversity indices for the Actinobacterial genera have been summarized in the Supplementary Table 3. The OTU richness of the Actinobacterial genera was studied by rarefaction analysis. Based on rarefaction analysis, the rarefaction curve of the $16 \mathrm{~S}$ rRNA gene sequences showed under-saturation suggesting further sequencing effort could lead to detection of rare sequences (Fig. 9c). The Shannon $\left(\mathrm{H}^{\prime}\right)$ index for all the Actinobacterial genera combined was 3.445, whereas the Simpson's index for the sequences was found to be 0.0336 (Supplementary Table 3). The overall richness for all the sequences combined and measured with the Chao 1 estimator was found to be 63.111 (Supplementary Table 3). In the phylotype frequency curve based on total number of 16S rRNA gene sequences generated in this study, the dominant OTU (OTU-14) consisted of 11 sequences belonging to Streptomycetales (10 sequences) and Micrococcales (1 sequence). Likewise, ten sequences were represented by 1 common OTU (OTU-33) containing Pseudonocardiales (5 sequences); and relatives as deposited in GenBank. Scale bar indicates 0.05 substitutions per site. The $16 \mathrm{~S}$ rRNA gene sequence of Methanobrevibacter smithii B181 is used as an outgroup

Corynebacteriales belonging to Mycobacteriaceae (3 sequences) and Nocardiaceae (2 sequences). Additional OTUs contained 4 sequences (4 OTUs) out of which 1 common OTU represented the family Nocardiodaceae of the order Propionibacteriales; 7 OTUs represented 3 sequences each and 8 OTUs with 2 sequences each. Whereas, $47 \%$ of the sequences were represented as singletons (20 OTUs) out of which 1 OTU represented the family Nocardiodaceae of the order Propionibacteriales (Fig. 9).

\section{Discussion}

Eastern Dharwar Craton (EDC) has witnessed various geological activities. The sampling site is an exposure, which is a part of EDC belt of granitic complex. Granites from EDC are significant mainly due to their Archaean age of existence and are one of the highly studied rock types due to the presence of minerals which are easily vulnerable to alterations. As apart, the mineral composition of these granite is such that, they 
Fig. 8 Neighbour-joining phylogenetic tree of the overall 16S rRNA gene sequences dataset for the phylum Actinobacteria, retrieved from GenBank and generated in the current study (green). Scale bar indicates 0.05 substitutions per site. 16S rRNA gene sequence of

Methanobrevibacter smithii B181 is used as an outgroup

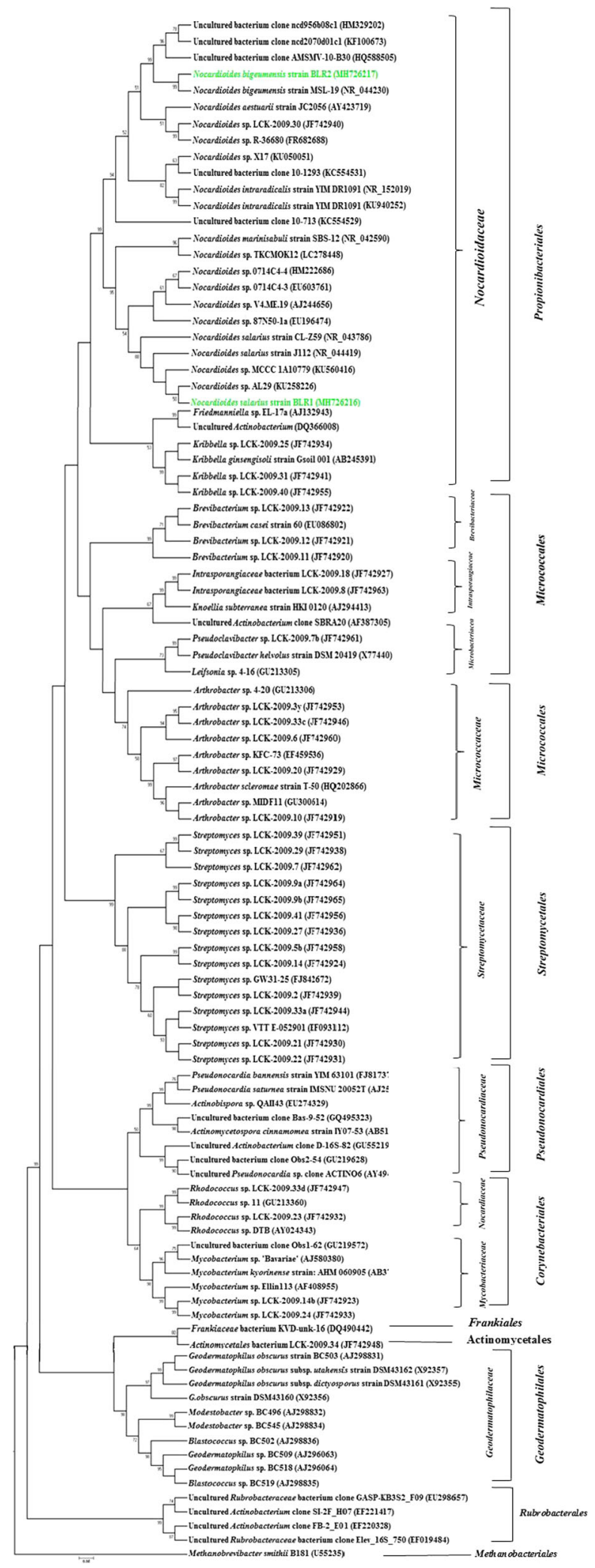




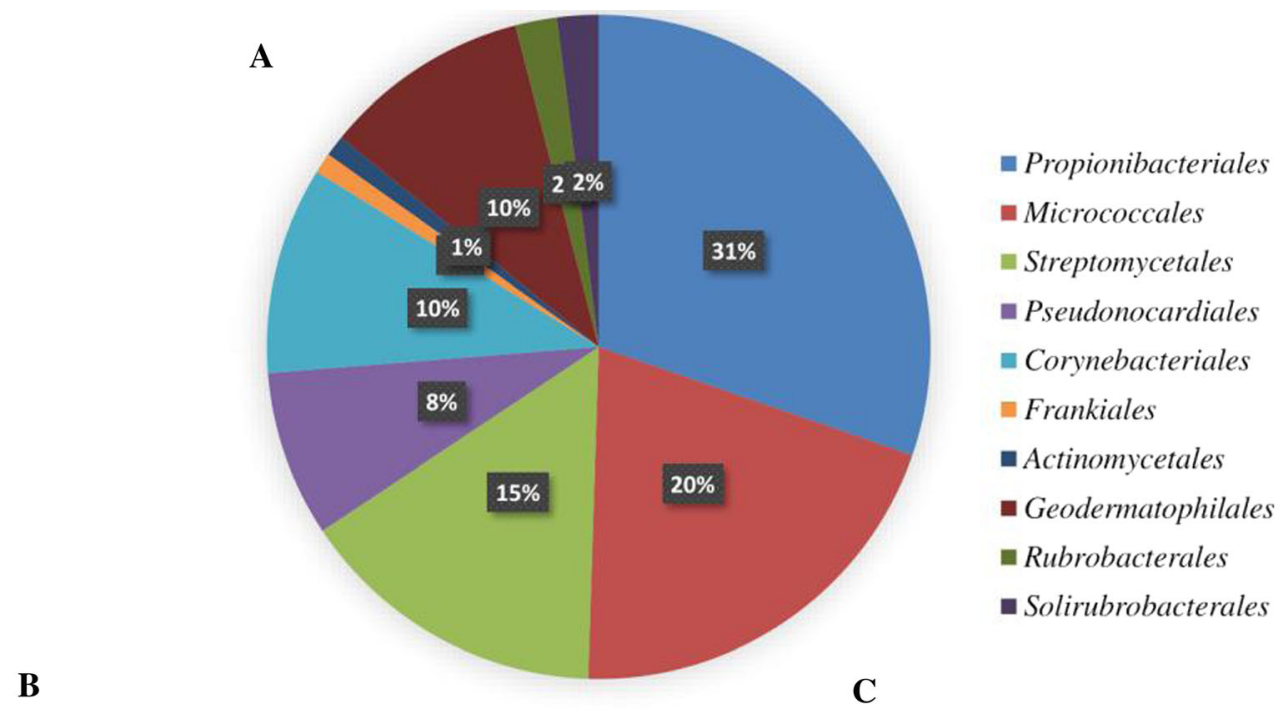

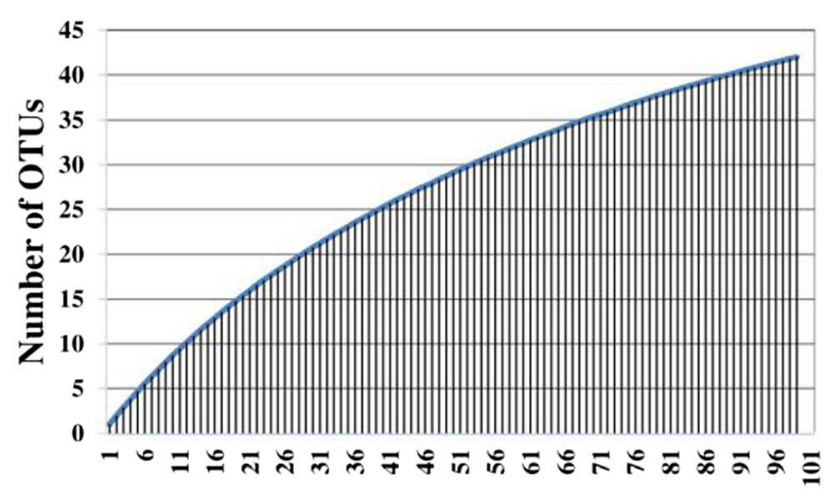

Total number of $16 \mathrm{~S}$ rRNA sequences

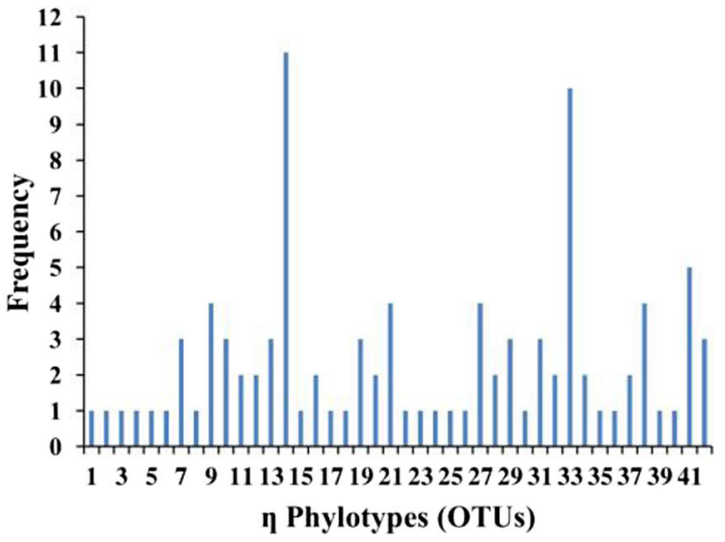

$\eta$ Phylotypes (OTUs)

Fig. 9 a Phylogenetic distribution of the studied sequence dataset within their respective orders. b Rarefaction curve from DOTUR analysis of the studied sequence dataset. c Phylotype frequency curve of the studied sequence dataset distributed among 42 phylotypes

form major nutrients to the major biosphere reserves in southern India (Jin et al. 2010; Akob and Kusel 2011).

The petrographic analysis by EPMA indicates the presence of major oxides such as $\mathrm{SiO}_{2}, \mathrm{Al}_{2} \mathrm{O}_{3}, \mathrm{~K}_{2} \mathrm{O}$, $\mathrm{FeO}, \mathrm{Na}_{2} \mathrm{O}$, and $\mathrm{CaO}$. The BSE (Back Scattered Electron) and XPL (Cross Polarized Light) (Fig. 2a) images of a non-weathered granite section shows lamellar twinning indicating the plagioclase grain and cross-hatched twinning of K-feldspar grain. The XPL (Cross Polarized Light) image (Fig. 2b) of a weathered granite section illustrates the microbial growth through pores and fractures causing chemical alterations of plagioclase mineral grain (arrow). The smooth surface grains are of quartz (BSE image; Fig. 2b).
The XRD data indicates presence of secondary clay minerals kaolinite and vermiculite in both the bioweathered granite samples (short term incubation and microcosm study) along with the primary minerals plagioclase, K-feldspar and biotite (Fig. 4). The higher predominance of the secondary minerals like kaolinite, vermiculite, chlorite and smectite in the microcosm sample indicates recent weathering which in this study could be an indication of accelerated rates of microbial metabolic processes (acidification, leaching) during the experiment period (Fig. 4b). Such secondary minerals were not observed in the control sets (Fig. 3). This is a clear evidence of the microbial processes that occur in the lithosphere leading to formation of secondary minerals and soil from larger rock-types (Turpault et al. 2008). The laterite soil 
formation due to weathering of the EDC region, that sustains large biosphere reserves like the Nilgiri (Deepthy and Balakrishnan 2005; Baskaran et al. 2012). It has been reported that the uplifting of Western Ghats with the onset of monsoonal climatic regime caused heavy rainfall $(>2000 \mathrm{~mm})$ in the west coast plains of Indian peninsula and lesser rainfall $(\sim 500 \mathrm{~mm})$ in the hinterland (Mysore plateau; Deepthy and Balakrishnan 2005). It takes several thousand years for $1 \mathrm{~m}$ fresh rock to weather (Nahon 1991). However, the temperature and precipitation can control the rate of chemical weathering (White and Blum 1995). In this study we show that microbial reductive dissolution of the rocks can play a crucial role in pacing up the weathering and clay formation (Cuadros 2017). Also as a biproduct also supports the biota sustaining on the soil to exchange nutrient through leaching and transport mechanism.

The FT-IR spectrum of the bio-weathered and garden soil samples (Fig. 5; Supplementary Table 1) showed the presence of hydroxyl stretching region of kaolinite at 3642 and $3695 \mathrm{~cm}^{-1}$ and as $\mathrm{Al}-\mathrm{OH}$ at $912 \mathrm{~cm}^{-1}$. The large band near $1036-1000 \mathrm{~cm}^{-1}$ corresponds to $\mathrm{Si}-\mathrm{O}$ stretching vibration and 995 , $1012 \mathrm{~cm}^{-1}$ as $\mathrm{Si}-\mathrm{O}$ stretch. These characteristic signals can be considered dioctahedral clay (Djomgoue and Njopwouo 2013). The hydroxyl stretching region of illite was detected at $3624 \mathrm{~cm}^{-1}$ and at $536 \mathrm{~cm}^{-1}$ and $754 \mathrm{~cm}^{-1}$ the $\mathrm{Al}(\mathrm{VI})-\mathrm{OSi}, \mathrm{Al}(\mathrm{IV})-\mathrm{OSi}$ of illite and kaolinite were detected. However, doublet of quartz at $789 \mathrm{~cm}^{-1}$ and $778 \mathrm{~cm}^{-1}$ with $\mathrm{Si}-\mathrm{O}-\mathrm{Si}$ of quartz (in plane) at $694 \mathrm{~cm}^{-1}$ and out of plane $\mathrm{Si}-\mathrm{O}$; $\mathrm{Fe}-\mathrm{O}$ out-of-Plane quartz at $685 \mathrm{~cm}^{-1}$ were detected in all the three samples.

Moreover, the weathering experiments also indicate of the efficiency of the Actinobacteria to leachout minerals from the specimens, signifying their role in ecosystem dynamics. The lowering of $\mathrm{pH}$ of culture media from 7.0 to 5.5 within first seven days of incubation indicates the release of organic acids such as lactic, citric, oxalic and gluconic acids. Actinobacterial strains produce such acids as a strategy to extract limiting nutrients such as $\mathrm{P}, \mathrm{K}, \mathrm{Ca}$ and $\mathrm{S}$ from the nutrient bearing substrate rocks through chemically altering the mineral surface (Fig. 6a; Delvasto et al. 2009). The further increase in $\mathrm{pH}$ during the exponential growth phase (8th to 27 th day; Fig. 6b) was due to the increase in K-feldspar dissolution rate, which increases with increase in $\mathrm{pH}$ due to consumption of $\mathrm{H}^{+}$ions from the solution (Roden 2008; Uroz et al. 2009). Moreover, albite dissolves at sub-neutral $\mathrm{pH}$ because of surface protonation, whereas, increased density of deprotonated surface results in increased mineral dissolution above $\mathrm{pH} 7$ (Roden 2008).

The organic acids, chelating substances and $\mathrm{pH}$ alterations influence the dissolution rate of minerals in solution (Uroz et al. 2009). Oxido-reduction, acidolysis and chelation are important metabolic processes evidenced in microbial mineral weathering (Welch et al. 2002; Uroz et al. 2009). Actinobacteria are well known producers of commercially important extracellular enzymes such as amylase and cellulase, which catalyse the hydrolysis of simple and complex carbohydrates that result in the production of organic acids (Malisorn and Nikhome 2014). These acids directly induce mineral dissolution through: (i) They adhere to mineral surface and form complexes with metal ions thereby extracting them, (ii) They catalyse the release of metals by weakening the oxygen links, (iii) They affect the saturation state of solution by creating imbalance between cations and anions and induce chelation of the metal ions (Welch et al. 2002; Hamdali et al. 2008). This is also supported by the significant reduction in rock weight during the experiment, which indicates the potential of Actinobacteria in mineral weathering (Supplementary Table 4).

With the mesophilic climatic condition and precipitation all through out the year the laterite, clayey soil, in this region is suggested to be the weathered granites, gneisses and migmatites (Kelly et al. 2010) the role of biological factors like endolithic bacterial groups play an important role in dissolution. The bio-weathering activity was further quantified in the ICP-MS analyses. It indicated the leaching of major nutritive cations. The increased leached-out concentration of $\mathrm{Ca}, \mathrm{Fe}$, $\mathrm{Mg}$ and $\mathrm{P}$ indicates the targeted action of Actinobacterial strains on plagioclase grains (albite) and biotite $\mathrm{Fe}(\mathrm{II})$ phyllosilicate. Since, the silicate tetrahedra in quartz is completely interlocked, no weathering occurs in quartz mineral. Biotite, a $\mathrm{Fe}(\mathrm{II})$ rich trioctahedral mica is the main Fe bearing mineral in granitic rocks and most gneisses that form important source of $\mathrm{Fe}, \mathrm{Al}$ and $\mathrm{K}$ in soils (Shelobolina et al. 2012). Studies report that the oxidation of $\mathrm{Fe}(\mathrm{II})$ in biotite (Arocena et al. 2012; Brookshaw et al. 2014) results in its alteration to smectite vermiculite and goethite. The reduced Fe concentration indicates considerable loss of $\mathrm{Fe}$ from 
the granite specimen suggesting possible Fe(II) oxidation in biotite. Feldspars are reported to be most susceptible to microbial attack than quartz due the presence of cations that react strongly with microbially produced organic acids (Song et al. 2010). However reduced action of Actinobacterial strains on orthoclase feldspar was observed in this study. Considerable leaching was seen in $\mathrm{Ca}$ indicating plagioclase weathering. Also, bacterial bio-weathering of granite indicates plagioclase to be more vulnerable (Song et al. 2007).

Actinobacteria are the dominant microbial communities of rhizosphere. The leaching activity of major nutrients from the rock types (Fig. Graphical abstract) by Actinobacterial strains clearly infers their role in bio-availing the immobile nutrients to plants in mobile forms. Such phenomenon of rock mineral leaching carried out by physical, chemical and biological agents is a key procedure for mobilization of nutritive cations from soil to tree roots (Puente et al. 2004; Gleeson et al. 2006; Gadd 2007; Lepleux et al. 2012).

The rhizosphere (Fig. Graphical abstract) which is the immediate region around the growing roots, is localized with chemical environment that alters the weathering rates in $\mathrm{E}$ (leaching zone) and $\mathrm{C}$ (partial weathering zone) horizons (Richter et al. 2007; Johnson et al. 2005). This is the critical zone where plants take up solutes through ionic exchange and $\mathrm{pH}$ reduction (as low as 3 ) enhancing mineral decomposition rates (Berner et al. 2004). The soil profile illustrates the blueprint of soil and topography of surrounding environment. The B horizon also called the "zone of accumulation", receives deposits of clay and iron oxides from the above A horizon. Furthermore, in the studied region, the regular precipitation all across the year leads to a high moisture content in the interface of $\mathrm{B}$ and $\mathrm{C}$ horizons, but a drier surface. The B and C horizons harbour deep tree roots which uptake leached minerals from the microbial and chemically mediated partially decomposed rocks, which is illustrated in Fig. Graphical abstract. Trees exude $\mathrm{H}^{+}$or $\mathrm{OH}^{-}$to equilibrate anion-cation balance in soil. The root exudates along with organic acids (ex: oxalate, acetate) and chelating ligands from microbes acidify soil and scavenge metal ions from metalbearing rock minerals. Owing to the presence of tight structure of silica tetrahedra in K-feldspar, it contributes in holding the $\mathrm{K}^{+}$ions from escaping. In albite, replacement of $\mathrm{Si}^{4+}$ ions by $\mathrm{Al}^{3+}$ ions weaken the silicon tetrahedra structure, however, in biotite mica sheets, the silica tetrahedra is squeezed between $\mathrm{Al}^{3+}, \mathrm{Mg}^{2+}, \mathrm{Fe}^{2+}$ and $\mathrm{K}^{+}$ions. Hence, the cations of feldspar, anorthite, albite and biotite are released into the saprolite with chemical alteration to secondary minerals like kaolinite and vermiculite (Fig. 2). In general, the weathering of granite minerals results in the formation of secondary minerals alongside leaching such as kaolinite from plagioclase and K-feldspar Eqs. (1), (2) and (3); vermiculite, goethite and gibbsite from biotite alterations Eq. (4).

General reactions of conversion of primary granite minerals to secondary minerals.

$$
\begin{aligned}
& 2 \mathrm{NaAlSi}_{3} \mathrm{O}_{8}(\text { Albite })+3 \mathrm{H}_{2} \mathrm{O}+2 \mathrm{CO}_{2} \\
& \rightarrow \mathrm{Al}_{2} \mathrm{Si}_{2} \mathrm{O}_{5}(\mathrm{OH})_{4}(\text { Kaolinite }) \\
&+\mathrm{H}_{4} \mathrm{SiO}_{4}(\text { Silicic acid }) \\
&+2 \mathrm{Na} \mathrm{HCO}_{3} \text { (Sodium Bicarbonate) }
\end{aligned}
$$

$$
\begin{aligned}
& \mathrm{CaAl}_{2} \mathrm{Si}_{2} \mathrm{O}_{8}(\text { Anorthite })+3 \mathrm{H}_{2} \mathrm{O}+2 \mathrm{CO}_{2} \\
& \rightarrow \mathrm{Al}_{2} \mathrm{Si}_{2} \mathrm{O}_{5}(\mathrm{OH})_{4}(\text { Kaolinite }) \\
&+\left.+\mathrm{Ca}\left(\mathrm{HCO}_{3}\right)_{2} \text { (Calcium Bicarbonate }\right)
\end{aligned}
$$

$2 \mathrm{KAlSi}_{3} \mathrm{O}_{8}(\mathrm{~K}$ - feldspar $)+3 \mathrm{H}_{2} \mathrm{O}+2 \mathrm{CO}_{2}$

$\rightarrow \mathrm{Al}_{2} \mathrm{Si}_{2} \mathrm{O}_{5}(\mathrm{OH})_{4}($ Kaolinite $)$

$+\mathrm{H}_{4} \mathrm{SiO}_{4}$ (Silicic acid)

$+2 \mathrm{KHCO}_{3}$ (Potassium bicarbonate)

$$
\begin{aligned}
\mathrm{K} & \left(\mathrm{Mg}_{2} \mathrm{Fe}^{2+}\right)\left[\mathrm{Si}_{3} \mathrm{Al}\right] \mathrm{O}_{10}(\mathrm{OH})_{2}(\text { Biolite }) \\
& +\mathrm{H}_{4} \mathrm{SiO}_{4}+\mathrm{Mg}^{2+}+\mathrm{H}_{2} \mathrm{O} \\
& \rightarrow \mathrm{Mg}\left(\mathrm{MgFe}^{3+}\right)\left[\mathrm{Si}_{3} \mathrm{Al}\right] \mathrm{O}_{10}(\mathrm{OH})_{2}(\text { Vermiculite }) \\
& +\mathrm{FeOOH}(\text { Goethite })+\mathrm{Al}(\mathrm{OH})_{3}(\text { Gibbsite }) \\
& +\mathrm{H}^{+}+\mathrm{K}^{+}
\end{aligned}
$$

The cations from the leached granite mobilize to upper horizons for plant uptake. Hence, this signifies the role of microbial rock weathering in mediating various biogeochemical cycles in the ecosystem.

The biogeographic Actinobacterial diversity studies signify the continuing role of Actinobacteria in bio-weathering of different rock types (El-Gohary 2011; Frey et al. 2010; Suihko et al. 2007). Dominance of Nocardioidaceae family belonging to the order Propionibacteriales was observed both in culture based and biogeographical diversity studies. The previous investigations indicated predominance of Nocardioides signifying their potential role in bio- 
weathering of granitic rocks at St. Katherine, Egypt, through acid production, metal leaching and phosphate and sulphate solubilization (Abdulla 2009). Consistent with this, we detected mineral leaching and acid production abilities by isolates belonging to Nocardioides in bio-weathering of granites from EDC. Micrococcales and Streptomycetales were the following abundant orders detected. Members of such genera have been recovered from volcanic environments suggesting their role in bio-weathering of volcanic rocks such as basaltic and obsidian glass and thus contribute in carbonate-silicate cycle (Cockell et al. 2013).

Interestingly, release of siderophore (Fe (III)specific chelate) and catechol derivatives produced by Streptomyces sp. are suggested to enhance the dissolution of iron containing minerals such as hornblende (Liermann et al. 2000; Kalinowski et al. 2000). Actinobacterial groups belonging to the genus Nocardioides, Streptomyces, Pseudonocardia and Nocardia have been recovered from decayed ancient stone from a tomb in Egypt as well as in Palaeolithic rock arts, suggesting their involvement in biodeterioration of rock substrates (Groth et al. 1999; Abdulla et al. 2008).

A study on volcanic rocks in Iceland reported diverse bacterial communities with Rubrobacteraceae of the phylum Actinobacteria to be dominant within crystalline basalt rocks suggesting their ancient lineage in volcanic rock bio-weathering (Cockell et al. 2013). Interestingly, another study reported the predominance of Rubrobacteraceae within volcanic ash deposits of Kilauea volcano, Hawaii, USA (GomezAlvarez et al. 2007). Geodermatophilaceae are an Actinobacterial family that are specialized in variety of biotopes, with dry and extreme biomes, predominately rock habitats (Nie et al. 2012; Trujillo et al. 2015). Colonization of such species on monuments and rocks in Mediterranean basin were investigated for their contribution to deterioration of rock materials (Urzi et al. 2001; Trujillo et al. 2015).

Most importantly the biogeographic study clearly indicates a global unavailability and ignorance of such an important environmental process, which bridges the gap between inorganic and organic global chemistry. Geodermatophilaceae are an Actinobacterial family that are specialized in variety of biotopes, with dry and extreme biomes, predominantly rock habitats (Nie et al. 2012; Trujillo et al. 2015). Colonization of such species on monuments and rock in Mediterranean basin were investigated for their contribution of deterioration of rock minerals (Urzi et al. 2001; Trujillo et al. 2015).

\section{Conclusion}

Overall this study focuses on the bio-weathering of EDC granite by indigenous endolithic genus Nocardioides. The multidisciplinary approaches to design experiment adopted analytical techniques, confirm the enhanced mineral leaching from granite acting a rich nutrient source to the poor soil quality in the belt. Furthermore, the microscopic analyses revealed the Actinobacterial biofilm formation also leads surface alterations in granite minerals, forming colonizing spots for other group microorganisms. Moreover, through an approach to understand the influence of bio-weathering in various biogeochemical cycles, it can be inferred that microbial rock weathering mediates the leaching of essential nutritive cations that form the life-sustaining resources for plants as well as other life forms in the critical zone and thus, contribute in equilibration of ecosystem dynamics. In addition, the biogeographic Actinobacterial diversity study provides an ideal framework of their distribution patterns in ecosystem and their various bio-weathering potential. Besides, the biogeographic diversity study of Actinobacterial genera in bio-weathering of monuments has an empirical significance in addressing attempts to restore monuments from biodeterioration.

Acknowledgements This research was supported by the DST Inspire Faculty Grant (DST/INSPIRE/04/2015/002362) awarded to DG by the Department of Science and Technology, Government of India awarded to DG. AC thanks to the Ministry of Earth Science, Gov. of India, for fellowship. Indian Institute of Science for provided central facilities like SEM, XRD, FTIR and EPMA etc. The authors thank Prof. Ramananda Chakrabarti (CEaS, IISc) for providing ICP-MS facility and Mr. Prakash Chandra Arya (CEaS, IISc) for his enormous assistance.

\section{References}

Abdulla H (2009) Bioweathering and biotransformation of granitic rock minerals by Actinomycetes. Microbial Ecol 58(4):753-761. https://doi.org/10.1007/s00248-009-95491

Abdulla H, May E, Bahgat M, Dewedar A (2008) Characterisation of Actinomycetes isolated from ancient stone and 
their potential for deterioration. Pol J Microbiol 57(3):213-220

Akob DM, Küsel K (2011) Where microorganisms meet rocks in the Earth's Critical Zone. Biogeosciences 8:3531-3543. https://doi.org/10.5194/bg-8-3531-2011

Alekseeva TV, Alekseev AO, Sapova EV, Gerasimenko LM (2009) Transformation of clay minerals caused by an alkaliphilic cyanobacterial community. Microbiology 78(6):776-784. https://doi.org/10.1134/ S0026261709060150

Arocena JM, Velde B, Robertson SJ (2012) Weathering of biotite in the presence of arbuscular mycorrhizae in selected agricultural crops. Appl Clay Sci 64:12-17. https://doi.org/10.1016/j.clay.2011.06.013

Banerjee A, Chakrabarti R, Mandal S (2016) Geochemical anatomy of a spheroidally weathered diabase. Chem Geol. 440:124-138. https://doi.org/10.1016/j.chemgeo.2016.07. 008

Baskaran N, Anbarasan U, Agoramoorthy G (2012) India's biodiversity hotspot under anthropogenic pressure: a case study of Nilgiri Biosphere Reserve. J Nat Conserv 20(1):56-61. https://doi.org/10.1016/j.jnc.2011.08.004

Battistuzzi FU, Hedges SB (2009) A major clade of prokaryotes with ancient adaptations to life on land. Mol Biol Evol 26(2):335-343. https://doi.org/10.1093/molbev/msn247

Battistuzzi FU, Feijao A, Hedges SB (2004) A genomic timescale of prokaryote evolution: insights into the origin of methanogenesis, phototrophy, and the colonization of land. BMC Evol Biol 4:44. https://doi.org/10.1186/1471-21484-44

Berner EK, Berner RA, Moulton KL (2004) Plants and mineral weathering: past and present. In: Drever JI (ed) Surface and ground water, weathering, and soils treatise on geochemistry, vol 5. Elsevier, San Diego, pp 169-188

Bradford M (1976) A rapid and sensitive method for the quantitation of microgram quantities of protein utilizing the principle of protein-dye binding. Anal Biochem 72(1-2):248-254

Brewer TE, Fierer N (2018) Tales from the tomb: the microbial ecology of exposed rock surfaces. Environ Microbiol 20(3):958-970. https://doi.org/10.1111/1462-2920.14024

Brookshaw DR, Lloyd JR, Vaughan DJ, Pattrick RAD (2014) Bioreduction of biotite and chlorite by a Shewanella species. Am Miner 99:1746-1754. https://doi.org/10.2138/ am.2014.4774CCBY

Calvaruso C, Turpault MP, Frey-Klett P (2006) Root-associated bacteria contribute to mineral weathering and to mineral nutrition in trees: a budgeting analysis. Appl Environ Microbiol 72(2):1258-1266. https://doi.org/10.1128/ AEM.72.2.1258-1266.2006

Camacho C, Coulouris G, Avagyan V, Ma N, Papadopoulos J, Bealer K, Madden TL (2009) BLAST+: architecture and applications. BMC Bioinform 10:421. https://doi.org/10. 1186/1471-2105-10-421

Chikkanna A, Ghosh D (2018) Microbial mineral dissolution and environmental disasters: microbes and their mineral interactions. In: Sharma P, Sharma A (eds) Microbial biotechnology in environmental monitoring and cleanup, vol 1, pp 125-151 https://doi.org/10.4018/978-1-52253126-5.ch008
Chikkanna A, Ghosh D, Kishore A (2018) Expression and characterization of a potential exopolysaccharide from a newly isolated halophilic thermotolerant bacteria Halomonas nitroreducens strain WB1. PeerJ 6:e4684. https:// doi.org/10.7717/peerj.4684

Cockell CS, Kelly LC, Marteinsson V (2013) Actinobacteriaan ancient phylum active in volcanic rock weathering. Geomicrobiol J 30(8):706-720. https://doi.org/10.1080/ 01490451.2012 .758196

Cuadros J (2017) Clay minerals interaction with microorganisms: a review. Clay Miner 52(2):235-261. https://doi.org/ 10.1180/claymin.2017.052.2.05

Deepthy R, Balakrishnan S (2005) Climatic control on clay mineral formation: evidence from weathering profiles developed on either side of the Western Ghats. J Earth Syst Sci 114:45-556. https://doi.org/10.1007/BF02702030

Delvasto P, Ballester A, Munoz JA, Gonzalez F, Blazquez ML, Igual JM, Valverde A, Garcia-Balboa C (2009) Mobilization of phosphorus from iron ore by the bacterium Burkholderiacaribensis FeGL03. Miner Eng 22(1):1-9. https://doi.org/10.1016/j.mineng.2008.03.001

Djomgoue P, Njopwouo D (2013) FT-IR spectroscopy applied for surface clays characterization. J Surf Eng Mater Adv Technol. 03(04):275-282. https://doi.org/10.4236/jsemat. 2013.34037

El-Gohary MA (2011) Analytical investigations of disintegrated granite surface from the un-finished obelisk in Aswan. J Archaeometry 35:29-39. https://doi.org/10.4000/ archeosciences.2909

Felsenstein J (1985) Phylogenies and the comparative method. Am Nat 125(1):1. https://doi.org/10.1086/284325

Frey B, Rieder SR, Brunner I, Plötze M, Koetzsch S, Lapanje A, Brandl H, Furrer G (2010) Weathering-associated bacteria from the Damma glacier forefield: physiological capabilities and impact on granite dissolution. Appl Environ Microbiol 76(14):4788-4796. https://doi.org/10.1128/ AEM.00657-10

Gadd GM (2007) Geomycology: biogeochemical transformations of rocks, minerals, metals and radionuclides by fungi, bioweathering and bioremediation. Mycol Res 111(1):3-49. https://doi.org/10.1016/j.mycres.2006.12. 001

Gadd GM (2010) Metals, minerals and microbes: geomicrobiology and bioremediation. Microbiology 156:609-643. https://doi.org/10.1099/mic.0.037143-0

Ghosh D, Bhadury P, Routh J (2018) Coping with arsenic stress: adaptations of arsenite-oxidizing bacterial membrane lipids to increasing arsenic levels. MicrobiologyOpen 7(5):e00594

Ghosh D, Kumar S, Donselaar ME, Corroto C, Ghosh AK (2021) Organic Carbon transport model of abandoned river channels - A motif for floodplain geomorphology influencing biogeochemical swaying of arsenic. Sci Total Environ 762:144400

Gleeson D, McDermott F, Clipson N (2006) Structural diversity of bacterial communities in a heavy metal mineralized granite outcrop. Environ Microbiol 8:383-393. https://doi. org/10.1111/j.1462-2920.2005.00903.x

Gomez-Alvarez V, King GM, Nusslein K (2007) Comparative bacterial diversity recent Hawaiian volcanic deposits of 
different ages. FEMS Microbiol Ecol 60:60-73. https://doi. org/10.1111/j.1574-6941.2006.00253.x

Groth I, Vettermann R, Schuetze B, Schumann P, Saiz-Jimenez C (1999) Actinomycetes in Karstic caves of northern Spain (Altamira and Tito Bustillo). J Microbiol Methods 36(1-2):115-122. https://doi.org/10.1016/S01677012(99)00016-0

Halvorson JJ, Gonzalez JM (2006) Bradford reactive soil protein in Appalachian soils: distribution and response to incubation, extraction reagent and tannins. Plant Soil 286(1):339-356. https://doi.org/10.1007/s11104-0069047-x

Hamdali H, Hafidi M, Virolle MJ, Ouhdouch Y (2008) Rock phosphate-solubilizing Actinomycetes: screening for plant growth-promoting activities. World J Microbiol Biotechnol 24(11):2565-2575. https://doi.org/10.1007/s11274008-9817-0

Horath T, Bachofen R (2009) Molecular characterization of an endolithic microbial community in dolomite rock in the central Alps (Switzerland). Microb Ecol. 58(2):290-306. https://doi.org/10.1007/s00248-008-9483-7

Huber T, Faulker G, Hugenholtz P (2004) Bellerophon: a program to detect chimeric sequences in multiple sequence alignments. Bioinformatics 20(14):2317-2319. https://doi. org/10.1093/bioinformatics/bth226

Johnson DL, Domier JEJ, Johnson DN (2005) Reflections on the nature of soil and its biomantle. Ann Am Assoc Geogr 95(1):11-31. https://doi.org/10.1111/j.1467-8306.2005. 00448

Jin L, Ravella R, Ketchum B, Bierman PR, Heaney P, White T, Brantley SL (2010) Mineral weathering and elemental transport during hillslope evolution at the Susquehanna/ Shale Hills Critical Zone Observatory. Geochim Cosmochim Ac 74:3669-3691. https://doi.org/10.1016/j.gca. 2010.03.036

Kalinowski BE, Liermann LJ, Givens S, Brantley SL (2000) Rates of bacteria-promoted solubilization of $\mathrm{Fe}$ from minerals: a review of problems and approaches. Chem Geol 169(3-4):357-370. https://doi.org/10.1016/S00092541(00)00214-X

Kavil SP, Ghosh D, Pašić I, Routh J (2020) Temporal dynamics of arsenic uptake and distribution: food and water risks in the Bengal basin. Toxicol Environ Chem 102(1-4):62-77

Kelly LC, Cockell CS, Piceno YM, Andersen GL, Thorsteinsson T, Marteinsson V (2010) Bacterial diversity of weathered terrestrial Icelandic volcanic glasses. Microb Ecol 60(4):740-752. https://doi.org/10.1007/s00248-010-96848

Kimura M (1980) A simple method for estimating evolutionary rates of base substitutions through comparative studies of nucleotide sequences. J Mol Evol 16(2):111-120. https:// doi.org/10.1007/BF01731581

Kroppenstedt RM (1985) Fatty acid and menaquinone analysis of Actinomycetes and related organisms. Soc Appl Bacteriol Techn Ser 20:173-199

Lane DJ (1991) 1991. 16S/23S rRNA sequencing. In: Stackebrandt E, Goodfellow M (eds) Nucleic acid techniques in bacterial systematics. Wiley, New York, pp 115-175

Lepleux C, Turpault MP, Oger P, Fre-Klett P, Uroz S (2012) Correlation of the abundance of Betaproteobacteria on mineral surfaces with mineral weathering in forest soils.
Appl Environ Microbiol 78(19):7114-7119. https://doi. org/10.1128/AEM.00996-12

Liermann LJ, Kalinowski BE, Brantley SL, Ferry JG (2000) Role of bacterial siderophores in dissolution of hornblende. Geochim Cosmochim Acta 64(4):587-602. https://doi.org/ 10.1016/S0016-7037(99)00288-4

Mailloux BJ, Alexandrova E, Keimowitz AR, Wovkulich K, Freyer GA, Herron M, Stolz JF, Kenna TC, Pichler T, Polizzotto ML, Dong H, Bishop M, Knappett PSK (2009) Microbial mineral weathering for nutrient acquisition releases arsenic. Appl Environ Microbiol 75(8):2558-2565. https://doi.org/10.1128/AEM.02440-07

Malisorn K, Nikhome K (2014) Isolation and screening of actinomycetes from soil for their enzymatic and antifungal activity. Khon Kaen Agric J 42(4):151-156

Manikyamba C, Kerrich R (2011) Eastern Dharwar Craton, India: continental lithosphere growth by accretion of diverse plume and arc terranes. Geosci Front 3(3):225-240. https://doi.org/10.1016/j.gsf.2011.11.009

Mapelli F, Marasco R, Balloi A, Rolli E, Cappitelli F, Daffonchio D, Borin S (2012) Mineral-microbe interactions: biotechnological potential of bioweathering. J Biotechnol 157(4):473-481. https://doi.org/10.1016/j.jbiotec.2011.11. 013

Mesbah M, Premachandran U, Whitman WB (1989) Precise measurement of the $\mathrm{G}+\mathrm{C}$ content of deoxyribonucleic acid by high-performance liquid chromatography. Int J Syst Bacteriol 39(2):159-167

Moore DM, Reynolds RC (1989) X-ray diffraction and the identification and analysis of clay minerals. Oxford University Press, New York

Nahon DB (1991) Introduction to the petrology of soils and chemical weathering. Wiley, New York, p 313

Nie GX, Ming H, Li S, Zhou EM, Cheng J, Yu TT, Zhang J, Feng HG, Tang SK, Li WJ (2012) Geodermatophilus nigrescens sp. nov., isolated from a dry-hot valley. Antonie Van Leeuwenhoek 101:811-817. https://doi.org/10.1007/ s10482-012-9696-0

Puente ME, Bashan Y, Lebsky VK (2004) Microbial populations and activities in the rhizosplane of rock-weathering desert plants. I. Root colonization and weathering of igneous rocks. Plant Biol 6(5):629-642. https://doi.org/10. 1055/s-2004-821100

Raczek I, Jochum KP, Hofmann AW (2007) Neodymium and strontium isotope data for USGS reference materials BCR1, BCR-2, BHVO-1, BHVO-2, AGV-1, AGV-2, GSP-1, GSP-2 and Eight MPI-DING reference glasses. Geostand Newsl 27:173-179. https://doi.org/10.1111/j.1751-908X. 2003.tb00644.x

Rahul P, Ghosh P, Bhattacharya SK (2016) Rainouts over the Arabian Sea and Western Ghats during moisture advection and recycling explain the isotopic composition of Bangalore summer rains. J Geophys Res Atmos 121:6148-6163. https://doi.org/10.1002/2015JD024579

Roden E (2008) Microbiological controls on geochemical kinetics 1: fundamentals and case study on microbial $\mathrm{Fe}(\mathrm{III})$ oxide reduction. In: Brantley S, Kubicki J, White A (eds) Kinetics of water-rock interaction. Springer, New York. https://doi.org/10.1007/978-0-387-73563-4_8

Richter DD, Oh NH, Fimmen RL, Jackson JA (2007) The rhizosphere and soil formation. In: Zoe C, Whitbeck J (eds) 
The rhizosphere-an ecological perspective, vol 1(8). Springer, New York, pp 179-200, IN1-IN2. https://doi.org/ 10.1016/B978-012088775-0/50010-0

Saitou N, Nei M (1987) The neighbour-joining method: a new method for reconstructing phylogenetic trees. Mol Biol Evol 4(4):406-425. https://doi.org/10.1093/ oxfordjournals.molbev.a040454

Schloss PD, Handelsman J (2005) Metagenomics for studying unculturable microorganisms: cutting the Gordian knot. Genome Biol 6(8):229. https://doi.org/10.1186/gb-2005-68-229

Shelobolina E, Xu H, Konishi H, Kukkadapu R, Wu T, Blothe M, Roden E (2012) Microbial lithotrophic oxidation of structural $\mathrm{Fe}(\mathrm{II})$ in biotite. Appl Environ Microbiol 78(16):5746-5752. https://doi.org/10.1128/AEM.0103412

Sievers F, Wilm A, Dineen D, Gibson TJ, Karplus K, Li W, Lopez R, McWilliam H, Remmert M, Söding J, Thompson JD, Higgins DG (2011) Fast, scalable generation of highquality protein multiple sequence alignments using Clustal Omega. Mol Syst Biol 7:539. https://doi.org/10.1038/msb. 2011.75

Song W, Ogawa N, Oguchi CT, Hatta T, Matsukura Y (2007) Effect of Bacillus subtilis on granite weathering: a laboratory experiment. CATENA 70(3):275-281. https://doi. org/10.1016/j.catena.2006.09.003

Song W, Ogawa N, Oguchi C, Hatta T, Mtsukura Y (2010) Laboratory experiments on bacterial weathering of granite and its constituent minerals. Geomorphol Relief Process Environ 16:327-336. https://doi.org/10.4000/ geomorphologie. 8038

Suihko ML, Alakomi HL, Gorbushina A, Fortune I, Marquardt J, Saarela M (2007) Characterization of aerobic bacterial and fungal microbiota on surfaces of historic Scottish monuments. Syst Appl Microbiol 30(6):494-508. https:// doi.org/10.1016/j.syapm.2007.05.001

Tamura K, Dudley J, Nei M, Kumar S (2007) MEGA4: Molecular Evolutionary Genetics Analysis (MEGA) software version 4.0. Mol Biol Evol 24(8):1596-1599. https:// doi.org/10.1093/molbev/msm092

Tomaoka J, Komagata K (1984) Determination of DNA base composition by reverse-phase high-performance liquid chromatography. FEMS Microbiol Lett 25:125-128. https://doi.org/10.1111/j.1574-6968.1984.tb01388.x
Trujillo ME, Goodfellow M, Busarakam K, Riesco R (2015) Modestobacter lapidis sp. nov. and Modestobacter muralis sp. nov., isolated from a deteriorated sandstone historic building in Salamanca, Spain. Antonie Van Leeuwenhoek 108(2):331-320. https://doi.org/10.1007/s10482-0150482-7

Turpault MP, Righi D, Utérano C (2008) Clay minerals: precise markers of the spatial and temporal variability of the biogeochemical soil environment. Geoderma 147(3-4):108-115. https://doi.org/10.1016/j.geoderma. 2008.07.012

Uroz S, Calvaruso C, Turpault MP, Sarniguet A, de Boer W, Leveau JHJ, Frey-Klett P (2009) Efficient mineral weathering is a distinctive functional trait of the bacterial genus Collimonas. Soil Biol Biochem 41(10):2178-2186. https:// doi.org/10.1016/j.soilbio.2009.07.031

Urzi C, Brusetti P, Salamone C, Sorlini F, Stackebrandt E, Daffenchio D (2001) Biodiversity of Geodermatophilaceae isolated from altered stones and monuments in the Mediterranean basin. Environ Microbiol 3:471-479. https://doi.org/10.1046/j.1462-2920.2001.00217

Van Breemen N, Finlay R, Lundstrom U, Jongmans AG, Giesler R, Olsson M (2000) Mycorrhizal weathering: a true case of mineral plant nutrition? Biogeochemistry 49(1):53-67. https://doi.org/10.1023/A:1006256231670

Ventura M, Canchaya C, Tauch A, Chandra G, Fitzgerald GF, Chater KF, van Sinderen D (2007) Genomics of Actinobacteria: tracing the evolutionary history of an ancient phylum. Microbiol Mol Biol Rev 71(3):495-548. https:// doi.org/10.1128/MMBR.00005-07

Welch SA, Taunton AE, Banfield JF (2002) Effect of microorganisms and microbial metabolites on apatite dissolution. Geomicrobiol J 19(3):343-367. https://doi.org/10.1080/ 01490450290098414

White AF, Blum AE (1995) Effects of climate on chemical weathering in watersheds. Geochim Cosmochim Acta 59(9):1729-1747. 7037(95)00078-E https://doi.org/10.1016/0016-

Publisher's Note Springer Nature remains neutral with regard to jurisdictional claims in published maps and institutional affiliations. 